\title{
USE OF A GEOGRAPHIC INFORMATION SYSTEM TO ASSESS RISK TO GROUND-WATER QUALITY AT PUBLIC-SUPPLY WELLS, CAPE COD, MASSACHUSETTS
}

By Julio C. Olimpio, Elizabeth C. Flynn, Saiping Tso, and Peter A. Steeves

U.S. GEOLOGICAL SURVEY

Water-Resources Investigations Report 90-4140

Prepared in cooperation with the

MASSACHUSETTS DEPARTMENT OF ENVIRONMENTAL PROTECTION, DIVISION OF WATER POLLUTION CONTROL

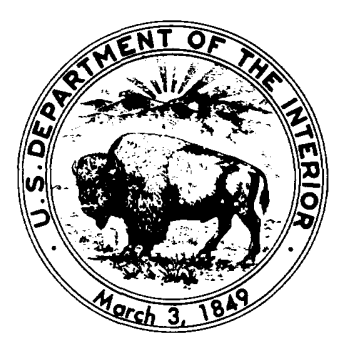

Boston, Massachusetts 1991 


\title{
U.S. DEPARTMENT OF THE INTERIOR
}

MANUEL LUJAN, JR., Secretary

\author{
U.S. GEOLOGICAL SURVEY
}

Dallas L. Peck, Director

For additional information, write to:

District Chief

Massachusetts - Rhode Island District

U.S. Geological Survey

Water Resources Division

28 Lord Rd., Suite 280

Marlborough, MA 01752
Copies of this report can be purchased from:

Books and Open-File Reports Section

U.S. Geological Survey

Box 25425, Federal Center

Denver, CO 80225 


\section{CONTENTS}

Page

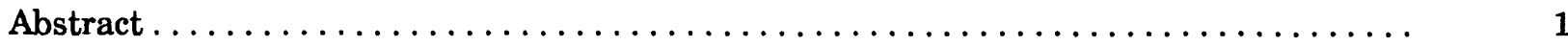

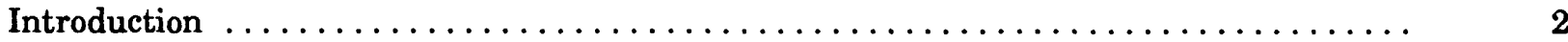

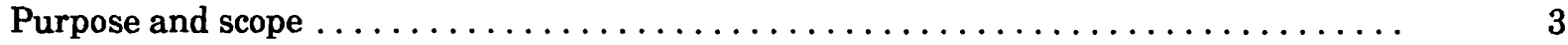

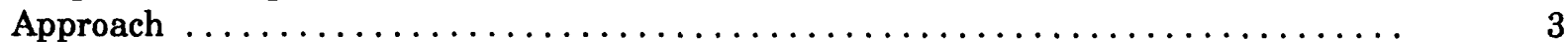

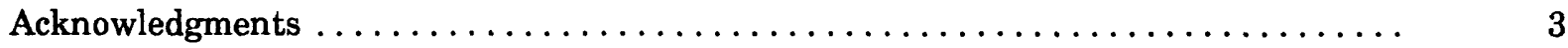

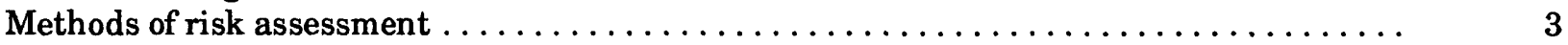

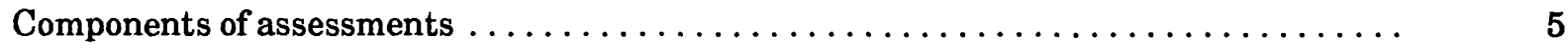

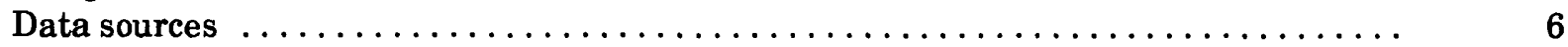

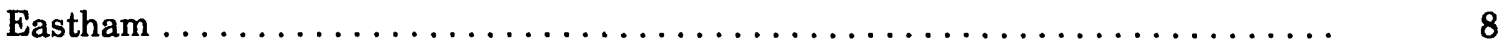

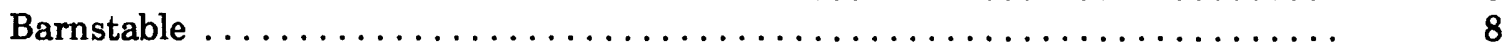

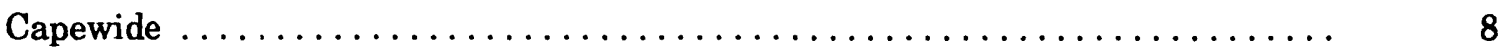

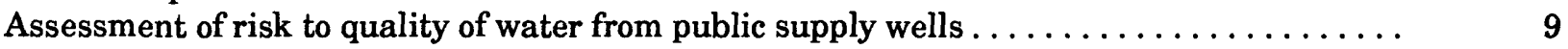

Screening for potential public water-supply sites $\ldots \ldots \ldots \ldots \ldots \ldots \ldots \ldots \ldots \ldots$

Risk to ground-water quality from land-use changes .................. 13

Intertown management: zones of contribution across town boundaries . . . . . . . . 15

Risk to ground-water quality from underground storage tanks $\ldots \ldots \ldots \ldots \ldots \ldots \ldots$.

Modeling nitrate concentration in ground water at public supply wells $\ldots \ldots \ldots \ldots \ldots .22$

Risk to ground-water quality from landfills $\ldots \ldots \ldots \ldots \ldots \ldots \ldots \ldots \ldots \ldots \ldots \ldots \ldots$

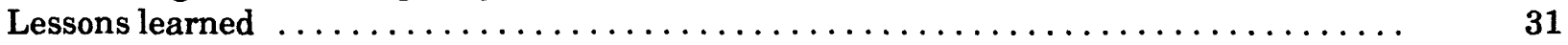

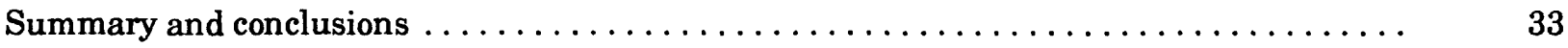

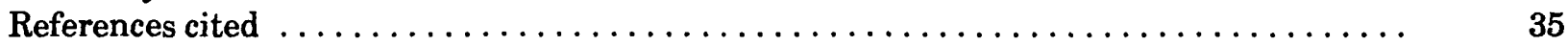

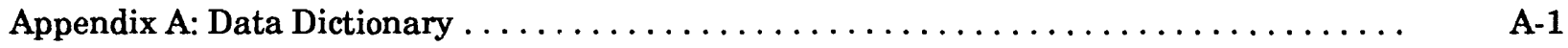

\section{ILLUSTRATIONS}

Figure 1-7. Maps showing:

1. Location of the study area, and selected zones of contribution to public-supply wells, Cape Cod, Massachusetts ........................ 4

2. Areas delineated for locating potential public water-supply sites, Eastham, Massachusetts . . . . . . . . . . . . . . . . . $\quad 11$

3. Potential public water-supply well sites, Eastham, Massachusetts . . . . . . . 12

4. Risk to public-supply wells from land use within the Barnstable

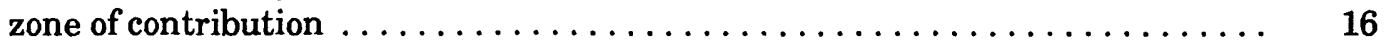

5. Land use and zoning within the Barnstable zone of contribution (1987) . . . . 17

6. Areas where land use and zoning conflict within the Barnstable zone of contribution . . . . . . . . . . . . . . . . . . . . . 19

7. Location of underground storage tanks in the zone of contribution to the Barnstable public-supply well field 


\section{ILLUSTRATIONS (Continued)}

8. Underground storage tank characteristics, ranking factors, and summary list of qualitative risk to water quality at public-supply wells ranked within the

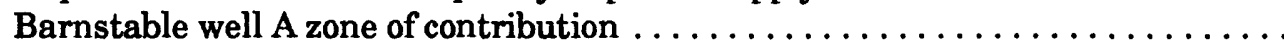

9-11. Maps showing:

9. Qualitative risk to ground-water quality from underground storage tanks in the zone of contribution for the Barnstable public-supply well field $\ldots \ldots \ldots \ldots$

10. Relative nitrate loads to ground water from different land uses within the Barnstable well field zone of contribution . . . . . . . . . . . . . . . .

11. Locations of public-supply wells, zones of contribution, and landfills, Cape Cod, Massachusetts (1987) . . . . . . . . . . . . . .

12. Landfill characteristics, ranking factors, and qualitative risk to water quality at public-supply wells, Cape Cod . . . . . . . . . . . . . . . . . .

\section{TABLES}

Table 1. Summary of technical and ground-water management issues considered for risk-assessment demonstration on Cape Cod ................... 5

2. Summary of selected assessment issues for the risk-assessment demonstration ..... 6

3. Data used to build the Cape Cod Geographic Information System data base $\ldots \ldots \ldots$. 7

4. Step-by-step approach used to identify potential public water-supply sites . . . . . . 10

5. Step-by-step approach used to evaluate potential risk to ground-water quality

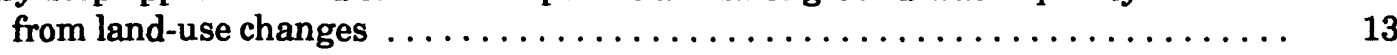

6. Changes in percentage of land use area within the Barnstable zone of contribution

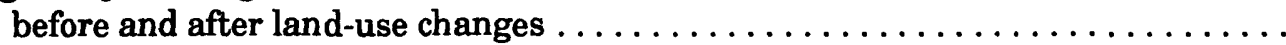

7. Step-by-step approach used to identify intertown management issues caused by zones of contribution that cross town boundaries

8. Distribution of land use and zoning in Barnstable and

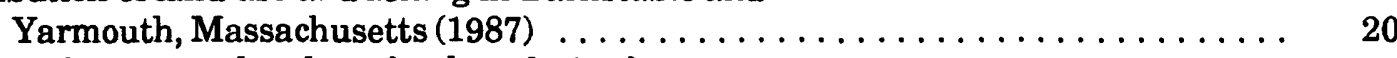

9. Ranking factors used to describe the relation between

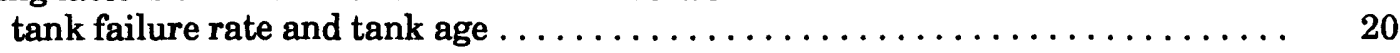

10. Step-by-step approach for estimating risk to a public-supply well from underground storage tanks within the zone of contribution .........

11. Step-by-step approach for calculating nitrate concentration in well water ...................

12. Step-by-step approach for assessing risk to public-supply sites from landfills 


\section{CONVERSION FACTORS AND VERTICAL DATUM}

\begin{tabular}{lcl}
\hline & Bultiply & To obtain \\
\hline inch (in.) & Length & \\
foot (ft) & 25.4 & millimeter \\
mile (mi) & 0.3048 & meter \\
& 1.609 & kilometer \\
gallon (gal) & Volume & liter \\
& 3.785 & \\
pounds, avoirdupois (lbs) & Mass & milligram \\
& 453,592 & cubic meter per second \\
cubic foot per second (ft/s) & Flow & cubic meters per day \\
million gallons per day (Mgal/d) & 0.02832 & meter per day \\
& 0.04381 & \\
foot per day (ft/d) & Hydraulic Conductivity & \\
& 0.3048 & \\
& &
\end{tabular}

Sea level: In this report "sea level" refers to the National Geodetic Vertical Datum of 1929--a geodetic datum derived from a general adjustment of the first-order level nets of the United States and Canada, formerly called Sea Level Datum of 1929. 


\title{
Use of a Geographic Information System To Assess Risk to Ground-Water Quality at Public-Supply Wells, Cape Cod, Massachusetts
}

\author{
By Julio C. Olimpio, Elizabeth C. Flynn, Saiping Tso, and Peter A. Steeves
}

\begin{abstract}
Methods for assessing the risk to ground-water quality at selected public-supply wells on Cape Cod, Massachusetts, were developed in a 9-month demonstration project in 1987. Geographic information system technology was used to store, manipulate, and analyze information from more than 30 data bases for Cape Cod and the towns of Barnstable and Eastham. Technical, management, and institutional issues identified by the Cape Cod Aquifer Management Project--a 2year study by the U.S. Environmental Protection Agency, the U.S. Geological Survey, the Massachusetts Department of Environmental Quality Engineering (now the Department of Environmental Protection), and the Cape Cod Planning and Economic Development Commission--(now the Cape Cod Commission) were used to select representative ground-water problems for analysis. Project objectives were to develop methods for assessing risk of ground-water contamination from sources within zones of contribution to water-supply wells that have been designated groundwater-protection areas. The land areas that lie directly above and that recharge zones of the water-table aquifer that contribute water to public-supply wells had previously been selected for use of ground-waterprotection strategies.
\end{abstract}

Three representative factors were chosen for analysis: the siting of future wells to minimize risk from potential contamination sources (Eastham); risk to wells from existing contaminant sources within a zone of contribution to a public-supply well (Barnstable); and assessment of risk to wells from sources within and upgradient to zones of contribution (Capewide). Six assessments were made to demonstrate methods of evaluating water-quality conditions at public-supply wells; these are (1) suitability of potential public water-supply sites, (2) risk to ground-water quality from land-use changes, (3) intertown management of zones of contribution across town boundaries, (4) risk to ground-water quality from underground storage tanks, (5) nitrate concentrations in public-supply well water, and (6) risk to ground-water quality from landfills.

The assessments were based on the development of step-by-step approaches that entailed data-overlay and buffering techniques for evaluating each representative water-quality issue. A buffer is a land zone within a specified distance of a point, line, or boundary of an area that is intended to reduce conflict between land uses or between physical features and land uses. Buffering is the act of creating such a zone. Numerous lessons were learned about planning, conducting, and completing a geographic information system-based demonstration project. Data problems included the unavoidable use of cartographically inaccurate base maps with different scales, multiple versions of data bases that did not match, and the need to convert large amounts of nongeographically referenced map and tabular data to digital data bases. Post-project evaluation revealed that too much time was spent on data 
gathering, too many part-time project staff participated in data compilation and verification, and too little time was allocated for the thorough testing and evaluation of analytical methods and results.

The results of this project include the development of an extensive digital data base for regional and local water-quality-related applications, the organization of a large amount of technical information, and the demonstration of overlay methods for evaluating a variety of potential contamination sources within an area that supplies water to a pumped supply well. These results are intended to demonstrate the utility of geographic information system technology for improving the efficiency of ground-water-protection planning.

\section{Introduction}

Ground water in the sole-source, sand and gravel aquifer on Cape Cod, Massachusetts, is plentiful and of chemical quality suitable for public supply. However, the water quality is vulnerable to changing land use, particularly the rapid conversion of undeveloped land to residential and commercial uses. Considerable efforts have been made to delineate wellhead-protection areas around the approximately 60 public water-supply wells on Cape Cod and to assess risk to ground-water quality from current and potential sources of contamination. Massachusetts has defined the wellhead protection area in $310 \mathrm{CMR} 22.20$ as "the area of an aquifer that recharges a well (the land surface which overlays that part of the aquifer that recharges a well) under the most severe recharge and pumping conditions that can be realistically anticipated" (Department of Environmental Quality Engineering, 1983 and 1986). This zone of contribution (ZOC) is "bounded by the ground-water divides that result from pumping the well and by contact of the edge of the aquifer with less permeable materials such as till and bedrock." The most recent effort to examine the many potential sources of contamination to ground water on Cape Cod was the Cape Cod Aquifer Management Project (CCAMP).

The CCAMP was initiated in 1986 by the U.S. Environmental Protection Agency (USEPA), Massachusetts Department of Environmental Quality Engineering (MDEQE), now the Department of Environmental Protection (MDEP), Cape Cod Planning and Economic Development Commission (CCPEDC), now the Cape Cod Commission (CCC), and the U.S. Geological Survey (USGS), to develop an integrated, resource-based approach to ground-water management involving Federal, State, regional, and local government. By the end of the project in January 1988, accomplishments included improvements in the definition of the ground-water resource, development of improved methodology for identifying and evaluating the potential adverse effects of different sources of contamination, and recommendations for adding protective measures to the institutional framework regulating potential contamination sources. CCAMP found that, despite greatly increased public awareness of the potential conflict between land development and ground-water quality protection, regulatory programs generally were not designed to manage existing land-use activities and reduce sources of potential contamination to water supplies within wellhead protection areas. The establishment of data bases for ground-water-protection planning has proceeded at an ever-increasing rate on Cape Cod, particularly in the last 5 years. Nevertheless, CCAMP determined that the lack of systematic, organized data-management activities at the regional and local levels has limited scientific analysis of water-resources information, and that this deficiency is a major obstacle preventing comprehensive determination of potential risks to public-water supplies.

Assessing risk to ground-water quality of wellheadprotection areas on Cape Cod requires the integration of a wide assortment of hydrologic, geologic, land use, and contamination-source data. However, the available data often are not on base maps with common scales and accuracies, data are not geographically referenced or, if tabular, can not be easily related to other identifiable map features. Similar data are collected by many agencies with different identification schemes with no way to cross-reference data for the same feature. At the town level, mapped information commonly is based on land-parcel maps which are not cartographically accurate. CCAMP recognized that geographic informations system (GIS) technology has emerged as an important tool to store, retrieve, analyze, and display environmental data. GIS capabilities make it possible to manipulate, overlay, and illustrate large amounts of complex information and solve data-organization problems. In February 1987, as a result of the interest spurred by ongoing CCAMP project activities, the Division of Water Pollution Control (MDEP), entered into a cooperative program with the USGS to conduct a 9-month, GIS demonstration project using data derived from CCAMP to assess risks to water quality of public-supply wells. 


\section{Purpose and Scope}

This report presents the results of a project that demonstrates GIS methods for assessing the risk to water quality of public-supply wells on Cape Cod, Massachusetts. Other project goals included the development of a computer data base at large scale, the establishment of a step-by-step approach for assessing risk, the delivery of a set of specified GIS map products, and the establishment of a regional GIS data base for future use.

The project, which was closely associated with the CCAMP project, began in April 1987 and ended in December 1987. Technical support for public presentations and preparation of "The Cape Cod Aquifer Management Project Final Report" for CCAMP continued through September 1988. The project area was located primarily in the two towns of Eastham and Barnstable, Cape Cod, Massachusetts (fig. 1). Demonstration methods were based largely on the environmental data gathered by CCAMP.

\section{Approach}

This demonstration GIS project relied on a project team composed of USEPA, MDEP, and CCC and USGS staff. Emphasis was placed on the development of a GIS data base using available CCAMP tabular data in digital and nondigital formats, mapped information from the CCAMP and the towns, and data from the USGS data base for Massachusetts. Project team members prepared a list of water-quality-related problems or scenarios to address. Attention was focused on wellhead-protection areas for public-supply wells, and on the sources of potential contamination to ground-water quality in those areas from contamination sources. The project team formulated six assessments demonstrating methods to assess the risk from landfills, underground storage tanks, nitrate loading, and other contamination sources associated with particular land uses. Project work included assistance in the preparation of a CCAMP Executive Summary Report (Cape Cod Aquifer Management Project, 1988), a CCAMP-GIS final report (Steppacher, 1988), and a series of public presentations complete with GIS poster displays. Between October 1987 and June 1988, approximately 14 presentations were given to Federal, State, and local groups.

\section{Acknowledgments}

This project was a team effort by members from each of the CCAMP participating agencies. Frequent and important contributions to the project were made by Michael MacDougall, Robin Fletcher, Ethan Mascoop, Deborah Cohen, Michael Kanohi, and Lee Steppacher of the USEPA, Roy Crystal, Tara Gallagher, and Gile Beye of the MDEP, and Gabriel Belfit of the CCC. The CCAMP Steering Committee provided oversight and guidance in formulating project objectives and defining goals. Generous assistance and base-map information was provided by the Barnstable Town Planning Office and the towns of Yarmouth and Eastham. The authors are also grateful to Joseph Moran who provided a detailed data base of privatesupply wells for the town of Eastham.

\section{METHODS OF RISK ASSESSMENT}

Project efforts concentrated on the assessment of risk from contamination sources within areas designated for ground-water protection. Consequently, the project approach was guided by the need to: (1) determine the location and extent of the designated wellheadprotection areas; (2) gather information on the sources of contamination within those areas; and (3) develop for each type of source, methods for ranking the relative sources of potential contamination to the quality of water in the well by using characteristics such as the distance to the well, volume of contaminant, and number of sources. In this report, a wellhead-protection area is defined as the land surface which lies directly over and recharges the zone of the aquifer that contributes water to the well, hereafter referred to as zone of contribution (ZOC), to a public water-supply well under normal pumping conditions. Methods of determining the zones of aquifers that contribute water to wells are described by Morrissey, 1986. These areas are the same as those also known on Cape Cod as the ZOC and in Massachusetts as the Zone II--land surface that contributes recharge to a public supply well as defined in 310 CMR 24.00 (the Massachusetts Aquifer Land Acquisition Program Regulations, 1983.) ZOCs that had been previously delineated by CCC, (Horsley, 1983, p. 366-392) and those from previous studies were used for the risk assessments. Because there were no public-supply wells in Eastham, a hypothetical well site and example ZOC were created to demonstrate the assessment process. For some individual public water-supply 


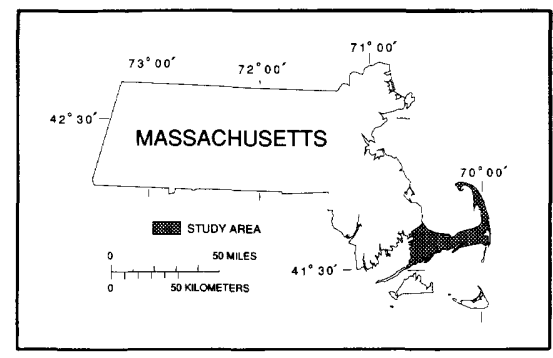

CAPE COD BAY
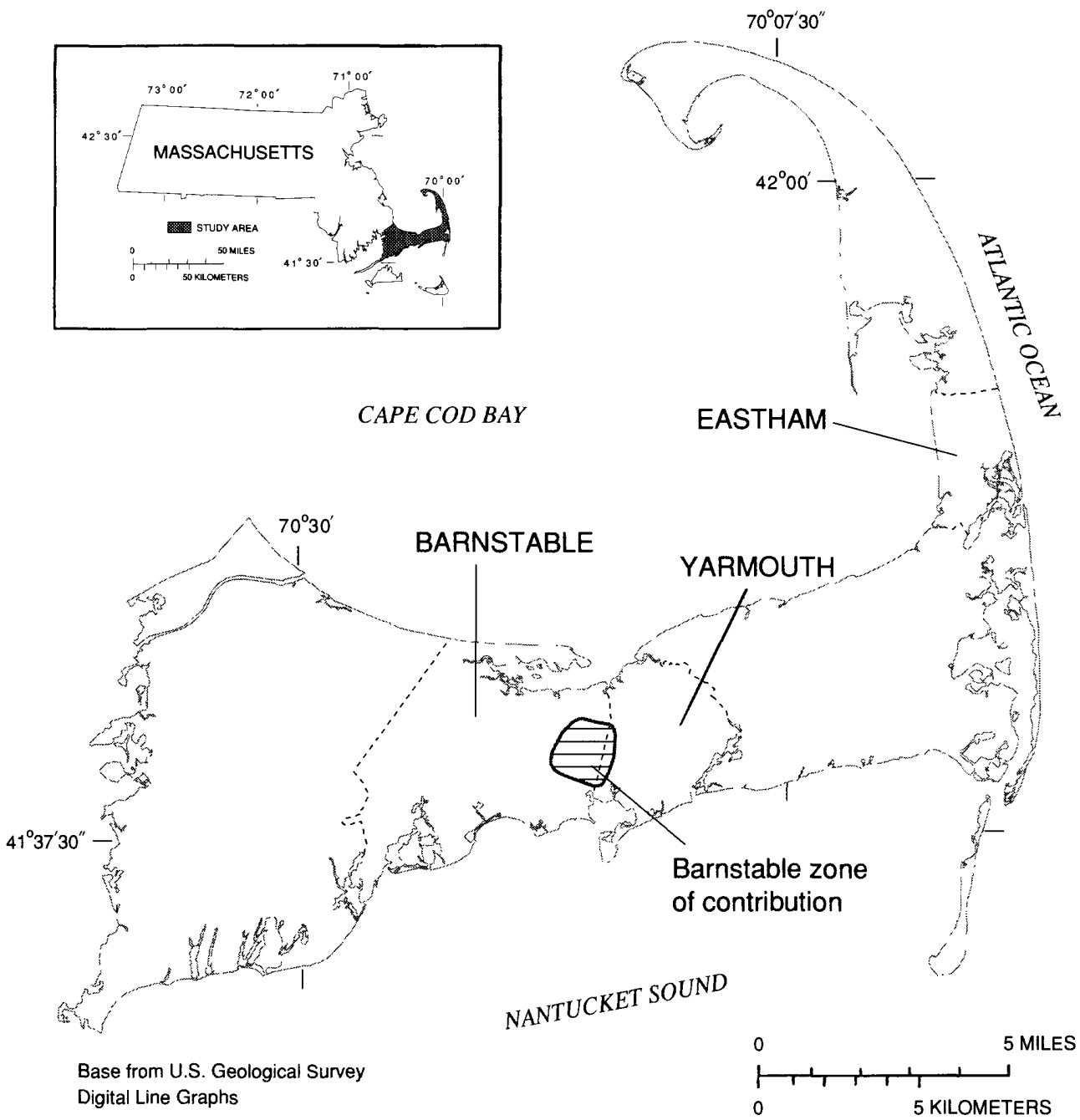

Figure 1.--Location of the study area, and zone of contribution to selected public-supply wells, Cape Cod, Massachusetts.

wells, example ZOCs were also defined to demonstrate the risk-assessment process.

One of the most important technical tasks of the project was to formulate ranking schemes for assessing the relative sources of potential contamination to ground-water quality from each type of potential contaminant source. The schemes used in this project were adapted from existing methodologies which are cited within this report. Project objectives did not include development of new ranking schemes specifically for Cape Cod.

Because of the demonstration nature of this project, three representative situations were selected for analysis: (1) The ZOC of one hypothetical public-supply well anticipated for the rural, seasonally populated town of Eastham, Massachusetts; (2) the composite
ZOC for nine public-supply wells within the highly-urbanized town of Barnstable, Massachusetts, (fig. 1); and (3) the ZOCs on Cape Cod. The three areas were chosen because they provided opportunities to help solve several current environmental problems, including assessment of risk to wells from existing sources within a ZOC (Barnstable), siting of future wells to minimize risk from potential contamination sources (Eastham), and assessment of risk to wells from sources within and upgradient from ZOCs (Capewide).

Although the large amount of available digital data compiled by the CCAMP encouraged almost immediate application of GIS technology, the most important task at the beginning of this project was the definition of technical issues pertinent to wellhead-protection which were of most concern to the participants. Con- 
siderable effort from the project team was necessary to clarify and condense technical concerns from the perspectives of each agency into clear, concise problem statements. Once the list of problem statements, herein referred to as assessments, was created, the list was used to identify data needs and to help design the structure and contents of the GIS data base.

The process of formulating the assessments used in this project is described in the following section. Subsequently, the data compiled for each of the assessments are described in the section.

\section{Components of the Assessments}

Each assessment consists of a problem statement, the identification of the data needed to address the problem, and the establishment of a step-by-step plan to solve the problem. A story board was created for each assessment to identify the type of data needed and the order in which the data were to be assembled, aggregated, and analyzed. A data-overlay approach was employed to help analyze the data.

Each of the participating agencies submitted potential assessments for consideration, and a list of 16 (table 1) was compiled for preliminary screening. As can be seen in table 1 , the list not only included technical issues pertaining to ground-water quality risks from contamination sources in specific areas, but also included many different management issues concerning town zoning, land use, growth plans, and hazardousmaterial regulations that are important to all towns on Cape Cod and to the CCC.

Table 1.--Summary of technical and ground-water management issues considered for risk-assessment demonstration on Cape Cod

[ZOC, zone of contribution]

\section{Eastham}

1. Identify potential sites for future public-supply wells.

2. Identify potential sites for stumps and (or) demolition waste storage.
3. Explore land-use development assessments that maximize protection of private-well water quality.

\section{Barnstable}

4. Apply a nitrate ground-water quality model to the land use within the ZOC.

5. Design a monitoring-well network for all known point-sources within the ZOC.

6. Rate risk to ground-water quality for each underground storage tank within the ZOC.

7. Develop a methodology to assess the comparative risk to ground-water quality from different types of contamination sources within the ZOC.

8. Identify potential sites for high-risk land-use activities.

9. Define intertown management issues pertaining to land use and zoning where ZOCs cross town boundaries.

10. Assess implementation of local, State, and Federal toxic and hazardous-materials regulations.

11. Determine priority areas for new sewer construction

\section{Capewide}

12. Compare ZOCs defined for existing publicsupply wells and regulatory setbacks or protection buffers with location and extent of known contaminant plumes.

13. Map all hazardous-waste facilities and ZOCs.

14. Examine number and location of high-risk transportation corridors crossing ZOCs and rank their risk to water quality.

15. Examine the impact of increasing the radius of regulatory buffer areas around public-supply wells from 400 feet to one-half mile.

16. Rate the risk to public-supply wells and their ZOCs from existing landfills.
The relatively short project timetable placed substantial limitations on the number of assessments that could be worked on. Consequently, several technical and management criteria were used to condense the list. These criteria included the appropriateness of the subject with respect to the mission of the USGS, the timeliness of the problem, the technical difficulty

\footnotetext{
${ }^{1}$ The use of product or trade names is for identification purposes only and does not constitute endorsement by the authors, the U.S. Geological Survey, the Massachusetts Department of Environmental Protection, the Cape Cod Commission or the U.S. Environmental Protection Agency.
} 
of the problem, the extent to which the problem provided insight into management of water resources, and the availability of data.

Six issues were chosen for the risk assessment demonstration (table 2). The final assessments satisfy the objectives of this project in that they represent the three study areas, require GIS methods to rank sources of contamination and to compare relative risk, address current technical, management, and institutional issues on Cape Cod, and illustrate the types of data gaps that occur and the data base management methods needed to support water-resources management activities. Analyses for each assessment were then performed with, or by means of GIS technology, as will be described in detail later in this report.

\section{Data Sources}

One of the key reasons why Cape Cod was selected for the demonstration project was the availability of base maps and other technical water resources data. The GIS data base that was developed for the project was assembled primarily from two sources of data-CCAMP and USGS data bases. It is important to note that the CCAMP data base was a compilation of data from many respected sources, including MDEP, USEPA, CCC, Massachusetts Department of Public Safety (MDPS), Barnstable County Health Department (BCHD), and from several agencies and fire departments in the towns of Barnstable, Eastham, and Yarmouth.

Table 2.--Summary of selected assessment issues for the risk-assessment demonstration

\section{Eastham}

1. Screening for potential public water-supply sites.

\section{Barnstable}

2. Risk from land-use changes.

3. Intertown management: zones of contribution across town boundaries.

4. Risk to ground-water quality from underground storage tanks.

5. Modeling nitrate concentration in water from a public-supply well.

\section{Capewide}

6. Risk to ground-water quality from landfills.
USGS data were compiled from existing GIS data bases as well as from Ground-Water Site Inventory (GWSI) and Quality of Water (QWDATA) data bases. The U.S. Environmental Protection Agency provided data from the FINDS (Facilities Index System) as well as from CCAMP-sponsored, USEPA water-table-mapping activities. Approximately 60 percent of the available data were in digital format, either on the USGS's Prime $^{1}$ computer or in CCAMP-compiled personal computer data bases. The remainder of the data was obtained by the project team either in traditional paper and mylar map formats or as files of tabular data. At the start of the project, 60 percent of the project schedule was set aside for data gathering, input into the computer, and conversion to GIS data bases. By the end of the project, over 90 percent of the project timetable had been devoted to data-related activities.

The categories of data that were compiled for the project GIS data base are listed in table 3. They are listed by geographic area which also corresponds to the way in which the GIS data base is organized. From the point of view of GIS technology, three types of data are represented: points (e.g., well sites); lines (e.g., roads); and polygons (e.g., land parcels). For the most part, the GIS data base consists of points, lines, or polygons as separate data layers. For example, the political boundaries for all of the towns on Cape Cod are stored as polygons in the Capewide town-boundary data layer.

The list of final selected assessments guided decisions on the desired scale and accuracy of the map and tabular data needed for each area. In the case of the Eastham well-screening assessment (table 2), the scope and level of difficulty of the problem included creation of digital data-layer coverages of land parcels, water-table contours, ponds, roads, town-owned land, national-seashore land, land-use zoning, private wells, and ZOCs. Therefore, the USGS's 7 1/2-minute topographic quadrangle maps at a scale of $1: 25,000$ were used as base maps for assembling data. For the more detailed and technically complex assessments within the Barnstable ZOC, it was necessary to assemble and map data at a much larger scale. The Barnstable Town Planning Office provided town tax assessor's land owner parcel maps at 1:7,200, which permitted highly-detailed data compilation. For the Capewide assessment, all of the digital data were obtained from 1:25,000 quadrangle maps, with only a few exceptions. 
Table 3.--Data used to build the Cape Cod Geographic Information System data base

\begin{tabular}{|c|c|c|c|c|}
\hline \multicolumn{2}{|c|}{ Data Categories } & Source $^{1}$ & Scale & Description \\
\hline \multicolumn{5}{|c|}{ Eastham } \\
\hline & CCAMP & $1: 25,000$ & Land use adjacent to Route 6 \\
\hline & Town-owned parcels & Eastham & & \\
\hline \multicolumn{2}{|c|}{ Private well sites } & Joseph Moran & & \\
\hline \multicolumn{2}{|c|}{ Cape Cod National Seashore } & USGS & $1: 25,000$ & \\
\hline \multicolumn{2}{|c|}{ Wetlands } & USGS & $1: 25,000$ & \\
\hline \multicolumn{2}{|c|}{ Non-community wells } & USEPAMDEP & $1: 25,000$ & $\begin{array}{l}\text { Large private-supply wells, such as for } \\
\text { condominiums }\end{array}$ \\
\hline \multicolumn{2}{|c|}{$\begin{array}{l}\text { ZOC boundaries } \\
\text { Barnstable }\end{array}$} & CCAMP & & \\
\hline \multicolumn{2}{|c|}{ Town land parcels } & Barnstable & $1: 7,200$ & Tax-assessment parcel boundaries \\
\hline \multicolumn{2}{|l|}{ Roads } & Barnstable & $1: 7,200$ & Outlines from parcel map \\
\hline \multicolumn{2}{|c|}{ Sewer lines } & Barnstable & $1: 12,000$ & \\
\hline \multicolumn{2}{|c|}{ Underground storage tanks } & CCAMP & $1: 7,200$ & Located by parcel \\
\hline \multicolumn{3}{|c|}{ Local by-law contamination sources CCAMP } & $1: 7,200$ & Hazardous materials handlers \\
\hline \multicolumn{2}{|c|}{ Zoning } & Barnstable & $1: 7,200$ & Both Barnstable and Yarmouth \\
\hline \multicolumn{2}{|c|}{ Water-table contours } & CCAMP & $1: 25,000$ & From 1987 CCAMP survey \\
\hline \multicolumn{2}{|c|}{ Observation wells } & CCAMP & $1: 25,000$ & From 1987 CCAMP survey \\
\hline \multicolumn{2}{|c|}{ FINDS sites } & USEPA & $1: 25,000$ & $\begin{array}{l}\text { Regulated facilities sites which are required } \\
\text { to report to USEPA }\end{array}$ \\
\hline \multicolumn{2}{|c|}{ Small-quantity generators } & CCAMP & & \\
\hline \multicolumn{2}{|c|}{ Land use } & Barnstable & $1: 7,200$ & \\
\hline \multicolumn{2}{|c|}{ ZOC boundaries } & CCC, SEA consultants & $\begin{array}{l}1: 7,200 \\
1: 48,000\end{array}$ & Nine-well composite map \\
\hline \multicolumn{5}{|c|}{ Capewide } \\
\hline \multicolumn{2}{|c|}{ Coastline } & USGS & $1: 25,000$ & \\
\hline \multicolumn{2}{|c|}{ Town boundaries } & USGS & $1: 25,000$ & \\
\hline \multicolumn{2}{|c|}{ Geographic names } & USGS & $1: 25,000$ & \\
\hline \multicolumn{2}{|c|}{ Community public-supply wells } & MDEP & $1: 25,000$ & Large public and privately owned wells \\
\hline \multicolumn{2}{|c|}{ Landfills (full outline) } & MDEP & $1: 25,000$ & \\
\hline \multicolumn{2}{|c|}{$\mathrm{ZOC}$ boundaries } & $\mathrm{CCC}$ & $1: 25,000$ & \\
\hline \multicolumn{2}{|c|}{ Ponds and streams } & USGS & $1: 25,000$ & \\
\hline Roads ar & railroads & USGS & $1: 25,000$ & \\
\hline Water qu & & USGS/BCHD/CCC & $1: 25,000$ & From USGS data bases \\
\hline Water-tal & e contours & USGS & $1: 48,000$ & Ten-foot contour interval \\
\hline Populatic & $(1980)$ & USGS & $1: 25,000$ & \\
\hline $\begin{array}{l}\text { Landfills, } \\
\text { ment pla }\end{array}$ & $\begin{array}{l}\text { alt piles, and waste-tr } \\
\text { s }\end{array}$ & - MDEP & $1: 25,000$ & MDEP Water-Supply Atlas (1984) \\
\hline Topograp & ic quadrangles & USGS & $1: 25,000$ & \\
\hline $\begin{array}{l}{ }^{1} \text { CCAMP } \\
\text { USGS } \\
\text { USEPA } \\
\text { MDEP }\end{array}$ & $\begin{array}{l}\text { Cape Cod Aquifer Man } \\
\text { U.S. Geological Survey } \\
\text { U.S. Environmental Prc } \\
\text { Massachusetts Depart } \\
\text { Environmental Protecti }\end{array}$ & $\begin{array}{l}\text { tion Agency } \\
\text { tt of }\end{array}$ & $\begin{array}{l}\text { CCC } \\
\text { BCHD } \\
\text { ZOC } \\
\text { FINDS }\end{array}$ & $\begin{array}{l}\text { Cape Cod Commission } \\
\text { Barnstable County Health Department } \\
\text { Zone of contribution } \\
\text { USEPA Facility Identification Standard site }\end{array}$ \\
\hline
\end{tabular}


A detailed description of the contents of the GIS data base developed in this project is given in Appendix A, Data Dictionary. All of the selected assessments used general Capewide base-map data; the following discussion describes the types and sources of additional map and tabular data obtained specifically for the Eastham, Barnstable, and Cape Cod risk-assessment assessments.

\section{Eastham}

The selected Eastham assessment relied heavily on Capewide base-map data and required the smallest amount of local information of the six assessments developed in this project. The town of Eastham provided information on the location of town-owned parcels and commercial parcels along State Route 6, which were identified on quadrangle maps from field work. Joseph Moran (Town of Eastham, written commun., 1987) provided a computerized data base of private-well-water quality by map and parcel number. Latitude and longitude locations for these private well sites were determined by CCAMP. The USEPA and MDEP gathered information for the public-supply wells that serve local condominium complexes and commercial businesses.

\section{Barnstable}

As mentioned earlier, a key to the development of the GIS data base for the Barnstable ZOC was the 1:7,200scale town tax assessor's maps of land parcel ownership available from the town planning office. Prior to the start of this project, CCAMP gathered a significant amount of data on existing and potential hazardouswaste sources and developed a computerized data base referenced by parcel number. For this project, the project team digitized the parcel map within the boundary of the ZOC (Horsley, 1983) and created a town-parcels data layer with more than 1,700 parcels. After the parcels in the GIS data layer were identified by parcel number, the computerized hazardous-waste data compiled by CCAMP were added to the town-parcels data layer by matching parcel numbers. As a result, the town-parcel data layer became one of the most important data layers in the GIS data base, because it contained not only information on the identity, area, and land use of each parcel, but also indicated the types of hazardous-waste material storage and handling activities related to land use and zoning.
A major part of the data in the Barnstable GIS data base was compiled by a CCAMP land-use study (Gallagher and Steppacher, 1987). Onsite surveys within the Barnstable $\mathrm{ZOC}$ were completed to verify the location, land use, and owner of each parcel. Additional surveys were made of State and local regulatory files to locate toxic and hazardous-waste material handling and storage areas, small-quantity hazardous-waste material generators, ground-water-discharge permittees, and underground-storage tanks.

CCAMP surveys were completed on the locations of various types of potential contamination sources and extensive information on each type of source was also compiled. For example, underground storage tanks were located with respect to parcel number. Then, characteristics of the tanks, including size, contents, age, and construction material, were recorded. Because of the project timetable, however, not all of the CCAMP information collected for each type of contamination source was entered into the GIS data base.

CCAMP provided observation-well and water-table data for 71 wells in the Barnstable ZOC from a 1986 field survey (Heath and Mascoop, 1988; p. c-2). The data were used to construct a water-table map of the project area and to assist in making a pollution-potential risk-assessment analysis of the Barnstable ZOC.

\section{Capewide}

The Capewide data base was developed from digital base-map information at a scale of 1:25,000 from existing USGS data bases. Base-map data included 7 1/2-minute quadrangle boundaries, town boundaries, and coastline configuration. Also available were the locations of ponds and streams, water-table contours, population, and geographic names. MDEP provided data on the location of public-supply wells, locations of landfills and their property boundaries, and a number of hazardous-waste storage and transfer facilities. CCC provided map information on the boundaries of ZOCs for most of the public-supply wells on Cape Cod and data on ground-water quality. 


\section{ASSESSMENT OF RISK TO QUALITY OF WATER FROM PUBLIC SUPPLY WELLS}

Six assessments were made to demonstrate the use of GIS methods in support of ground-water resources management. The assessments which follow are not intended to solve specific problems for the benefit of the towns of Eastham or Barnstable, but are intended to be examples of methods which can be applied in other areas and jurisdictions.

\section{Screening for Potential Public Water-Supply Sites}

In small towns on Cape Cod like Eastham, water supply for large, private condominiums, and business or industrial users is provided by individual wells. A substantial growth rate is related to the change from a mostly seasonal population to one that is permanent and year-round. Rapid land development and an increasing number of incidences of ground-water contamination have resulted. Growing concern about the likelihood of increasing contamination of private wells has spurred town interest towards locating a site for a large capacity public water-supply well where there is little or no sources of potential contamination to water quality.

A GIS approach was used in this project to screen the town for possible sites that would sustain a 1-Mgal/d public-supply well. Three assumptions were used to guide the screening approach: (1) The well would be located on town land, (2) The well would not be located in the residential area west of the major north-south highway (U.S. Route 6), and (3) The well would not be located inside the boundaries of the Cape Cod National Sea Shore (CCNSS).

The selected GIS overlay method consisted of 11 steps (table 4). Starting with a map of the town boundary, potential sources of potential contamination to ground-water quality, including existing commercial properties and a highway corridor (U.S. Route 6) were located. In conformance with State public-well-supply permit requirements, a $400-\mathrm{ft}$ buffer was placed around these areas. Next, all ponds and wetlands were located and a $150-\mathrm{ft}$ buffer was placed around each surface-water feature. The particular size of the surface-water buffer zone was chosen to help minimize the hydraulic effects of pumping a 1-Mgal/d well, on the basis of USGS observation-well data and experience in southeastern Massachusetts. All townowned parcels were identified, and those within the boundary of the CCNSS were eliminated from further consideration as well as all other town-owned parcels less than 5 acres in size. By overlaying and eliminating from consideration each of the buffer areas delineated around commercial properties, roads, and surface-water bodies, an area of suitable remaining land in the town was identified. By overlaying the remaining town-owned land parcels on the map of suitable land area, a number of potential well sites were identified (fig. 2).

After several potential well sites were identified, the next step in the screening process was to estimate the size of a potential ZOC to a 1-Mgal/d well in Eastham. Two methods were used to estimate the size of the hypothetical ZOC. The first used a two-dimensional analytical model developed by Bear (1979) and the hydrogeologic properties of the sand-and-gravel aquifer in Eastham. A parabolic-shaped ZOC was calculated. For the purpose of this analysis, the results were simplified to describe a circular-shaped ZOC. Assuming a water-table gradient of 0.0014 , a saturated thickness of $80 \mathrm{ft}$, and a horizontal hydraulic conductivity of $225 \mathrm{ft} / \mathrm{d}$, the calculated radius of the $\mathrm{ZOC}$ for a $1-\mathrm{Mgal} / \mathrm{d}$ well is $850 \mathrm{ft}$. The CCAMP recommended additional research on the techniques for delineation of the ZOC; as a result, a program supported by the State of Massachusetts, Barnstable County and the USGS began in 1987.

The second method used was based on a mass-balance approach using the equation for the area of a circle and an aquifer recharge rate of $25 \mathrm{in} / \mathrm{yr}$. This resulted in a calculated circular $\mathrm{ZOC}$ with a radius of $2,740 \mathrm{ft}$--a distance nearly equal to the interim $1 / 2$-mi wellheadprotection distance enacted by the State of Massachusetts in 1987. The size of the ZOCs estimated by both methods, as compared with the size of the town of Eastham, is shown in Figure 2B.

The final steps in the screening process involved overlaying the $\mathrm{ZOC}$ areas on the map of remaining land area and (or) town-owned parcels. ZOC areas determined by the Bear analytical method were centered on town-owned parcels and fitted inside of the boundary of the remaining land area. The result was the determination of a number of well sites that satisfied the environmental criteria adapted in this assessment (fig. 3).

Because of their relatively large size, only two ZOC areas determined by the mass-balance method fit into 
Table 4.--The step-by-step approach used to identify potential public water-supply sites [ZOC, zone of contribution; $\mathrm{ft}$, foot;Mgal/d, million gallons per day]

Assessment

Screening for potential public watersupply sites
Step-by-Step Approach

Comments

1. Obtain a town boundary map.

2. Identify commercial properties along Route 6 and place a 400-ft buffer around each.

3. Place a 400-ft buffer around Route 6 .

4. Eliminate buffered areas around commercial properties and roads from the town area to show the remaining area.

5. Place a 150-ft buffer around all ponds and wetlands.

6. Eliminate buffered pond and (or) wetland areas from the remaining land area.

7. Eliminate town-owned parcels within the Cape Cod National Seashore.

8. Select town-owned parcels east of Route 6 that are larger than 5 acres. Add to map of remaining land area.

9. Calculate the radius of the $Z O C$ for a hypothetical 1-Mgal/d well.

10. Determine potential well sites by overlaying $\mathrm{ZOC}$ areas on the map of remaining land area and (or) townowned parcels greater than 5 acres.

11. Plot 1/2-mile ZOCs around selected town parcels.

12. (Optional) Locate the position of private wells.
Minimize water-quality degradation by placing large buffers around areas that represent the greatest potential threat.

Massachusetts water-quality regulation.

Minimize the effects of pumping a large capacity well on the volume of water in surface-water bodies.

Cape Cod National Seashore does not permit the siting of a water-supply well within its boundaries.

Do not site a potential well in the residential area west of Route 6 . Provide the town with as much ownership of the well site as possible.

A public-supply well does not exist in the town. An estimate of the size of a representative $\mathrm{ZOC}$ in the town, given the hydrogeologic characteristics of the aquifer, is needed.

Center the ZOC on town-owned parcels and fit as many as possible within the boundary of the remaining land area.

Compare the calculated $Z O C$ area with the State's $1 / 2$-mile regulatory buffer area.

Determine the proximity of private homes for purposes of planning a water-delivery system from alternate well sites. 


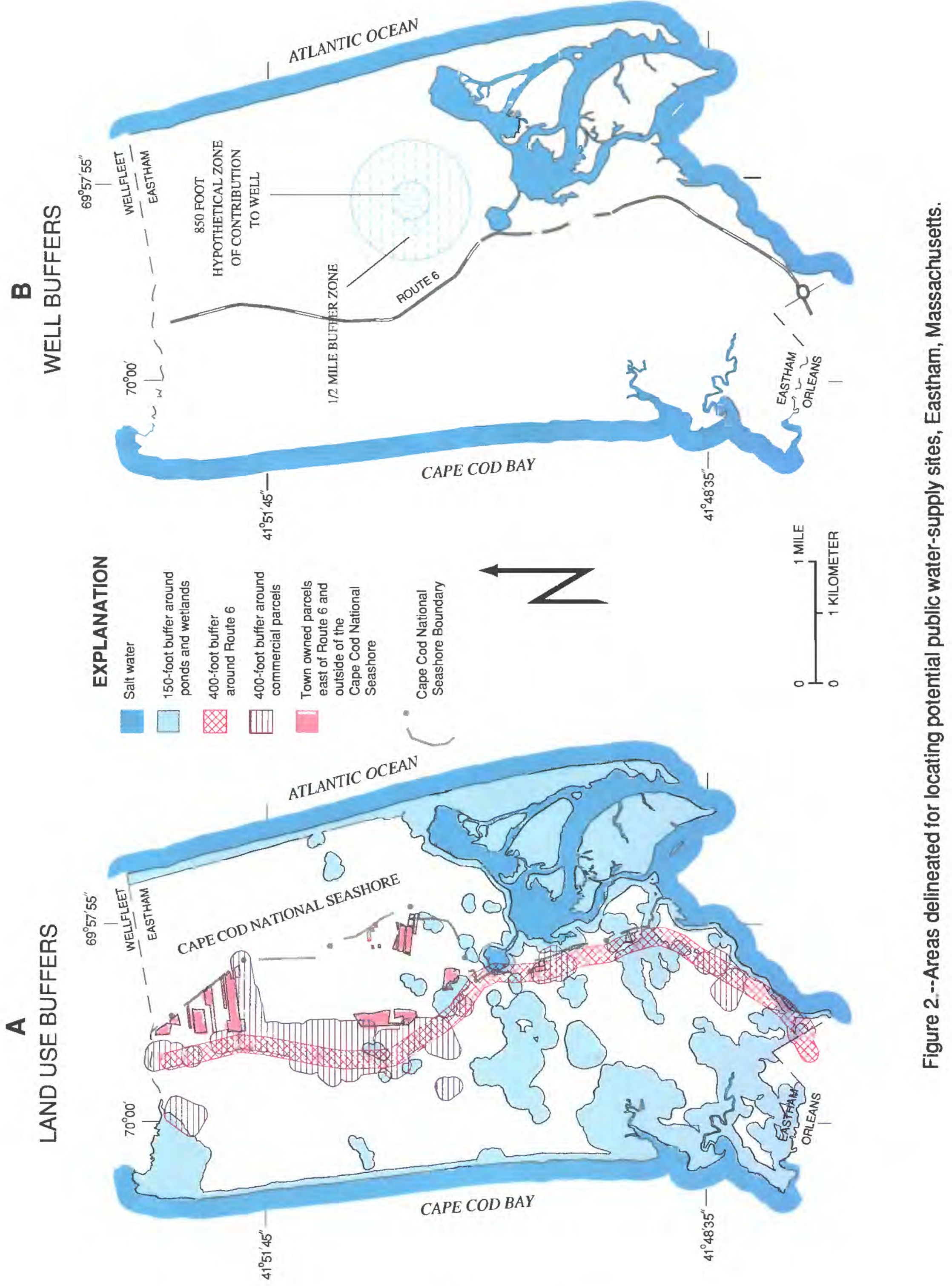




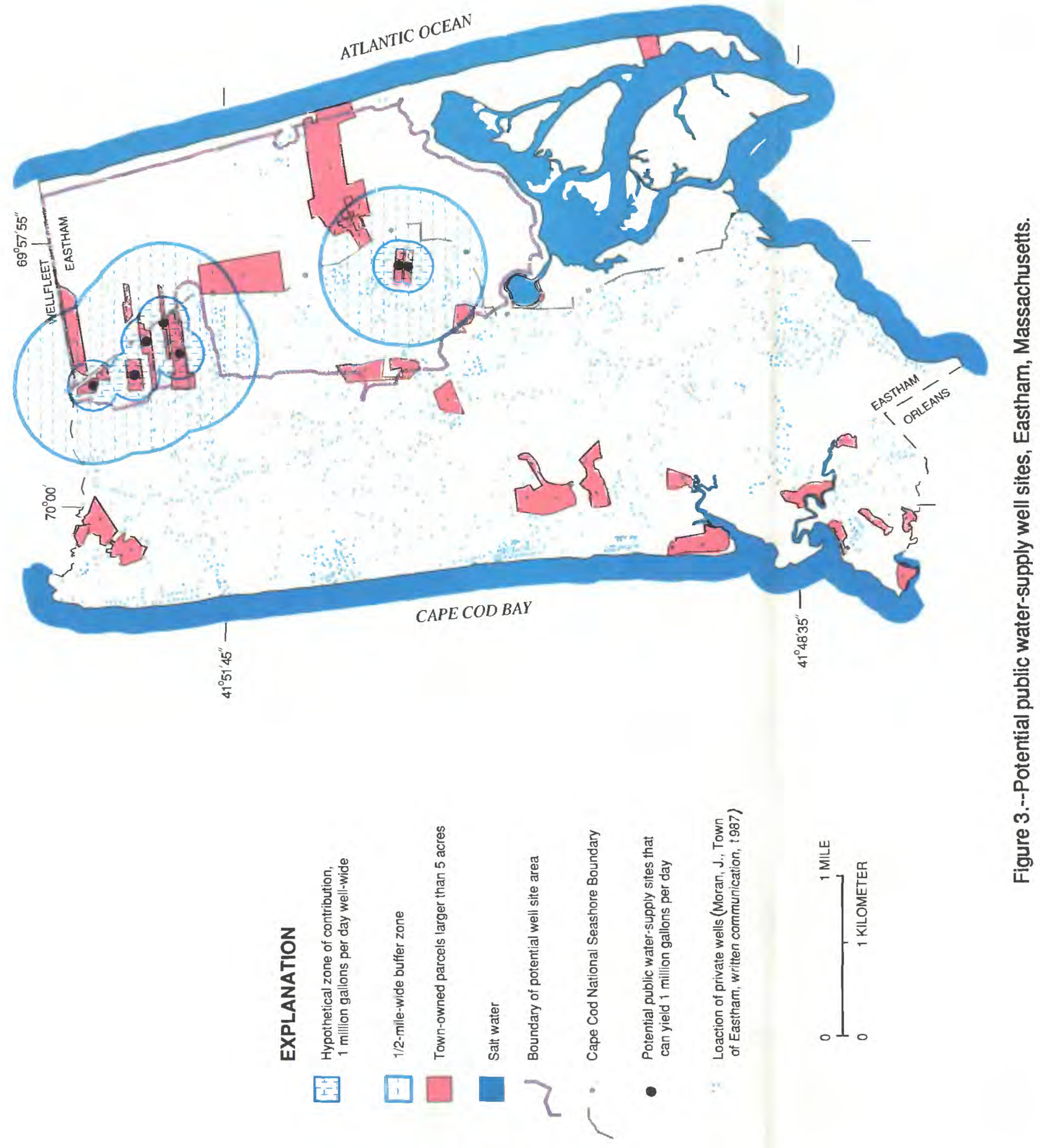


the remaining area (fig. 3). In the case of the southernmost town-owned land parcels that satisfied the criteria used in this assessment, one with a $1 / 2-\mathrm{mi}$ wide buffer fit within the remaining land area. In the case of the northernmost town-owned land parcels that were identified in this assessment, however, one area with a 1/2-mi buffer extends beyond the boundaries of the remaining area across the northern town boundary, and across Route 6, depending on the town parcel chosen.

This assessment demonstrates how a relatively small amount of data on land parcels, roads, and surfacewater features can be combined with qualitative estimates of $\mathrm{ZOC}$ areas to assist in screening a town area for potential water-supply sites. This prototype also shows how environmental and regulatory buffer areas can be included in the analysis and how the process of elimination works in narrowing the choice of suitable sites. When towns such as Eastham decide to select new well sites, a screening approach similar to the example demonstrated in this assessment can help to guide the selection process.

\section{Risk to Ground-Water Quality From Land-Use Changes}

Growth management and the establishment of institutional processes for planning and controlling land development has become the single most important public environmental issue on Cape Cod. Traditionally, town planners have used zoning maps to help keep track of growth and guide allowable development and land-use changes. But as growth has continued, additional incidences of ground-water contamination of local water supplies have been reported, and concern for the current and potential risk to water supplies has become a top priority.

For undeveloped areas, a zoning map can guide future development. By comparing current with future allowable land-use development in the vicinity of public-supply wells, qualitative information can be obtained on the likelihood of ground-water-quality degradation.

In this assessment, determination of the potential risk to public-supply wells focused on the combined, 3,650acre $\mathrm{ZOC}$ for the nine public-supply well sites, and six future sites for the town of Barnstable (Zoto and Gallagher, 1988; p. 41). The step-by-step method (table 5) was based on the aggregation of more than

Table 5.--The step-by-step approach used to evaluate potential risk from land-use changes

Assessment

Potential risk from landusechanges

\section{Step-by-Step Approach Comments}

1. Obtain land-parcel map of Bamstable ZOC.

2. Compile more than 100 land uses into 16 representative land-use categories and rank in order of increasing potential sources contamination to ground- water quality.

3. Sum the area of land parcels for each land use and calculate percentage of total ZOC area. Prepare a map of current land use.

4. Assume undeveloped vacant land parcels are built according to current zoning regulations and prepare a second map and associated area percentages by following steps 1-3.
Combine land uses into a relatively small number of generalized uses. Place these in order according to estimated potential risk to water quality using best judgment.

Determine current proportions of each type of land use and (or) risk category and compare with potential change percentages.

Hypothesize full change land development situation and determine change in percentage of high-risk land uses that can increase risks to publicwater supplies. 
100 land uses within the Barnstable ZOC into 16 generalized land-use categories. The 16 selected land uses were then ranked in order of increasing potential sources of potential contamination to water quality, and a risk scale ranging from low to high was assigned to each land use. A map of current land use was prepared illustrating the 16 representative land-use categories (fig 4A). The area of each land use (before change) was calculated as a percentage of the total ZOC area (table 6). Using the zoning map of the town as a guide, a second map was prepared according to projected allowable land-use change (fig. 4B), and the land-use percentages after change were recalculated.
This assessment is an example of how land-use and zoning information gathered in the vicinity of publicsupply wells can be assembled and combined to answer 'what-if' questions concerning potential sources of potential contamination to ground-water quality. In the case of full change shown in Figure 4B, the development of many vacant parcels in the central and northern part of the Barnstable ZOC that are presently zoned for industrial development can increase the risk to water supplies substantially. Viewing the data in this way, and using the automated capability of GIS technology to assemble and present information rapidly, local officials have an important

Table 6.--Changes in percentage of land use area within the Barnstable zone of contribution before and after land-use changes

[ZOC, zone of contribution]

\begin{tabular}{|c|c|c|c|}
\hline \multirow{2}{*}{\multicolumn{2}{|c|}{ Land use }} & \multicolumn{2}{|c|}{ Percentage of the Barnstable $\mathrm{ZOC}$ area } \\
\hline & & \multirow{2}{*}{$\frac{\text { Before land-use change }}{3.0}$} & \multirow{2}{*}{$\frac{\text { After land-use change }}{3.0}$} \\
\hline 1. & Open land & & \\
\hline 2. & Undevelopable land & 3.6 & 3.6 \\
\hline 3. & Developable residential & 13.1 & 0 \\
\hline 4. & Developable commercial & 1.2 & 0 \\
\hline 5. & Developable industrial & 18.1 & 0 \\
\hline 6. & Entertainment & .7 & .7 \\
\hline 7. & $\begin{array}{l}\text { Residential, single family, and } \\
\text { multifamily }\end{array}$ & 10.4 & 23.5 \\
\hline 8. & $\begin{array}{l}\text { Hotels, motels, inns, and } \\
\text { restaurants }\end{array}$ & 3.2 & 3.2 \\
\hline 9. & Offices and public services & 1.4 & 1.4 \\
\hline 10. & Retail & 4.3 & 4.3 \\
\hline & $\begin{array}{l}\text { Storage, warehouse, and } \\
\text { distribution }\end{array}$ & .6 & .6 \\
\hline 12. & Industrial storage & 2.0 & 3.2 \\
\hline 13. & Auto related & 3.5 & 3.5 \\
\hline 14. & Industrial & 18.4 & 36.5 \\
\hline 15. & Publicly-owned land & 14.3 & 14.3 \\
\hline 16. & Waste disposal & 2.2 & 2.2 \\
\hline To & & 100.0 & 100.0 \\
\hline
\end{tabular}


and valuable tool for evaluating water-resources issues in the context of land-use and zoning regulations.

\section{Intertown Management: Zones of Contribution Across Town Boundaries}

The ZOC of a public-supply well can extend across jurisdictional boundaries and be subject to land-use zoning designed for diverse and, perhaps, incompatible goals. The ZOC for the Barnstable public-supply wells is an example of a ZOC that crosses town boundaries (figs. 4 and 5). Although the town of Barnstable could enact land-use and zoning controls that minimize the risk to ground-water quality in Barnstable, the town of Yarmouth might not share similar landuse and zoning priorities for that part of the ZOC which lies in Yarmouth.

Table 7.--Step-by-step approach used to identify intertown management issues caused by zones of contribution crossing town boundaries

[ZOC, zone of contribution]

Assessment Step-by-Step Approach

Comments
This potential land-use incompatibility requires careful and continuous intertown communication, coordination, and management. The purpose of this assessment was to map the land uses and zoning within the $\mathrm{ZOC}$ area of each town and to identify incompatibilities in the patterns of land use and zoning across town boundaries that could increase the sources of potential contamination to ground-water quality.

The first step in the method of approach (table 7) was to aggregate land uses for all of the land parcels within the ZOC into five general types--residential, business, industrial, publicly owned, and undeveloped. A map of the Barnstable ZOC showing the distribution of the five land-use types was prepared (fig. 5A). Next, the zoning maps for the towns of Barnstable and Yarmouth were grouped into three general categories: residential, business, and industrial (fig. 5B). Comparison of the land use and zoning maps can reveal

\section{Intertown}

management:

zones of

contribution

across town

boundaries
1. Obtain a land-parcel map of the Barnstable ZOC.
2. Aggregate land uses in Barnstable and Yarmouth into five general categories.

3. Sum the area of land parcels for each type of land use and calculate percentage of ZOC area.

4. Prepare map of general land-use categories for ZOCC.

5. Prepare zoning map of Barnstable and Yarmouth and calculate percentage of each zone classification within the ZOC area.

6. Overlay three-category zoning map on a similar and-use map and identify parcels where classifications disagree.

7. Prepare map showing the resulting land use and (or) zoning disagreement.
Simplify land-use types into those types compatible with basic zoning types.

Assemble data on land uses in the ZOC within each town.

Assemble data on zoning in the ZOC within each town.

Identify where land use does not conform to zoning.

Identify areas within the ZOC where non- conforming use could jeopardize water-quality protection areas. 


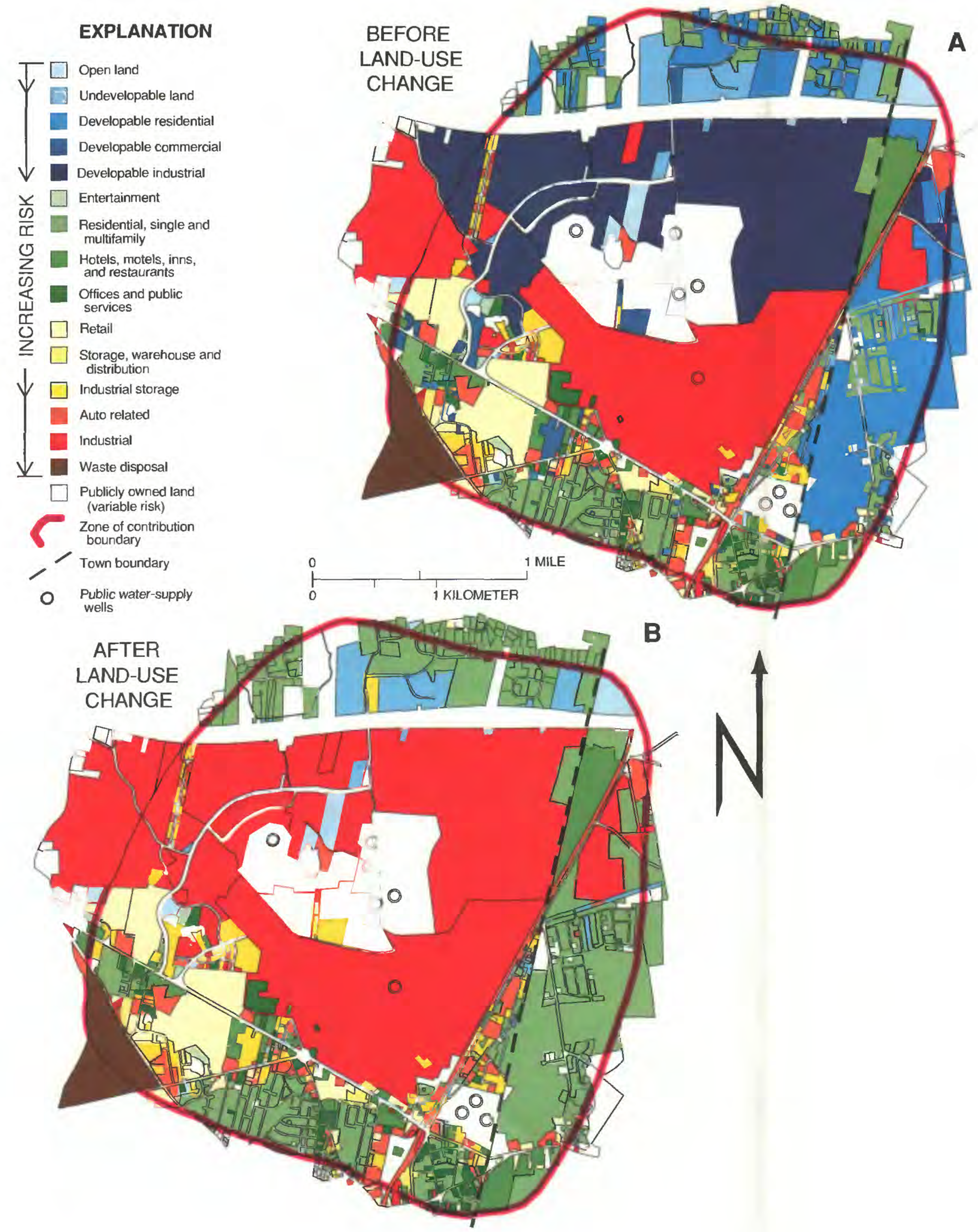

Figure 4.--Risk to public-supply wells from land use in the Barnstable zone of contribution. 


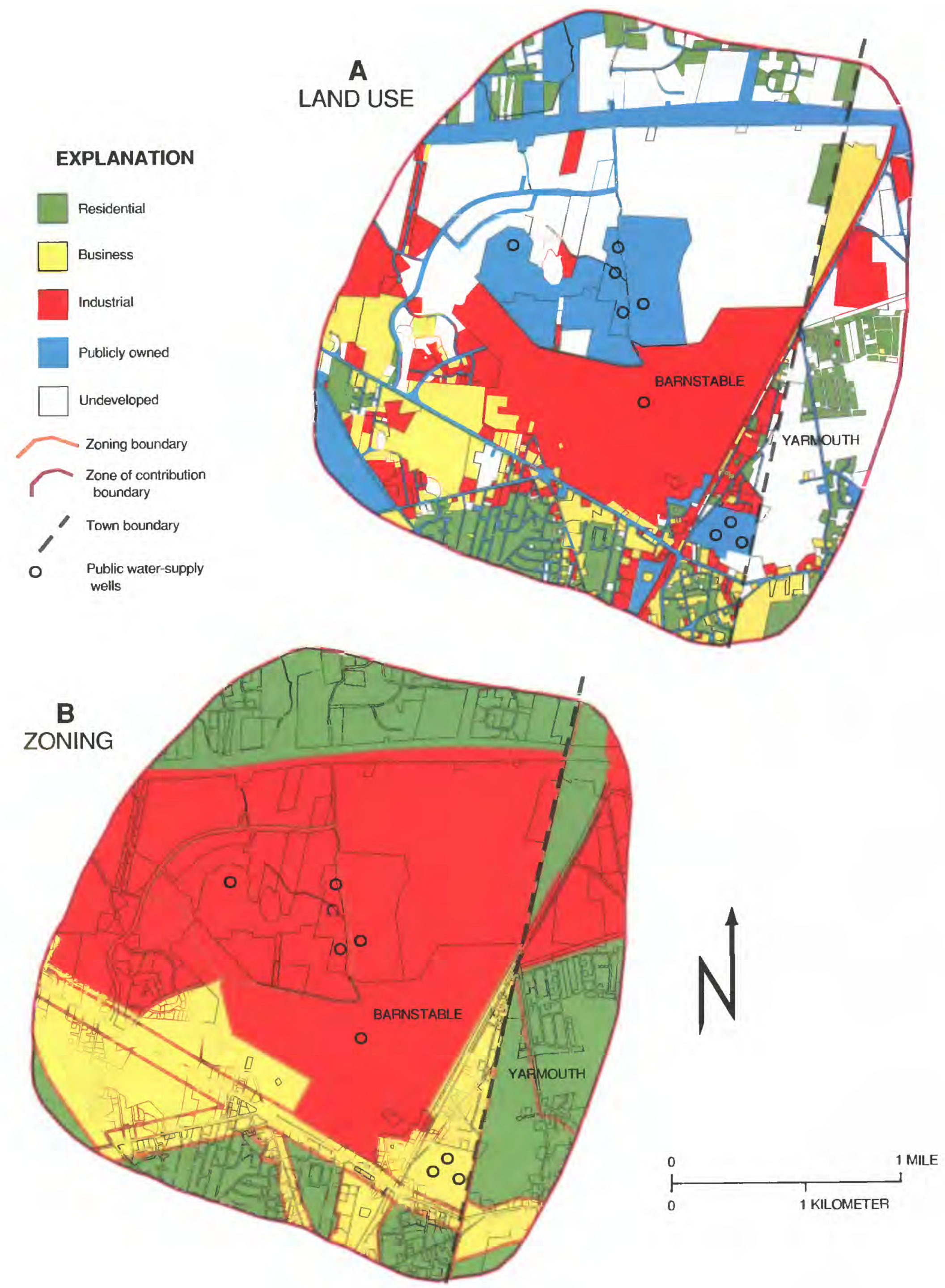

Figure 5.--Land use and zoning within the Barnstable zone of contribution (1987). 
intratown incompatibilities and, near the town boundaries, intertown incompatibilities.

Finally, a 3-category land-use map (residential, business, industrial) was compared with a similar 3-category zoning map to identify areas where land-use and zoning classifications did not agree. Six combinations of land-use versus zoning incompatibility were identified, and a shaded map was prepared showing the type and location of these areas (fig. 6).

The result of this assessment was the identification of town areas within both Barnstable and Yarmouth where land-use and zoning classifications can be nonconforming or inconsistent with ground-water-protection plans. Comparison of the land uses in the ZOC in both towns (table 8), shows that Barnstable has a greater percentage of high-risk land uses than does Yarmouth. For example, 23.7 percent of the land is industrial in the Barnstable part of the $\mathrm{ZOC}$, while only 8.4 percent is industrial in the Yarmouth part. Similarly, 59.1 percent is zoned for industrial use in Barnstable, while 27.7 percent is so zoned in Yarmouth. It is unknown whether the lower risk to wells in Barnstable from land uses in Yarmouth is fortuitous or by design, but this analysis helps to focus on the greatest sources of potential contamination. Application of this method to assess the magnitude of land-use contamination threats and identify jurisdictional responsibility for them can be an illuminating tool for developing cooperation between towns or other governmental units that share stewardship for ground-water resources.

Identifying and mapping land uses that do not agree with zoning can be used to evaluate the effectiveness of zoning that was designed to protect well-water quality. On the map in figure 6, for example, the large number of land parcels zoned for business, but actually used for industry, could represent an unanticipated sources of potential contamination to ground-water quality, especially for the wells in the southeastern corner of the ZOC. Although only a few small parcels of land zoned for low-risk residential are actually used for high-risk industrial, several of those parcels are close to some wells. Follow-up inventory of the industries on the identified land parcels could further define potential risks.

The method demonstrated in this assessment is neither difficult nor time-consuming and can be repeated through the use of automated techniques. Land-use changes occur rapidly, and overlay analyses can become quickly outdated, emphasizing the need for frequent data collection and reanalysis.

\section{Risk to Ground-Water Quality From Underground Storage Tanks}

In 1987, CCAMP completed an inventory of underground storage tanks within the ZOC of a Barnstable well field (Gallagher and Steppacher, 1987). The inventory identified 186 tanks located on 82 sites. Additional information was gathered for each tank including age, size, contents, and type of tank material. Summarizing some of the important data gathered during the inventory: 116 of 186 tanks were still in use, 71 tanks were 20 years or older, 122 tanks were constructed of steel, and the total storage volume represented by all tanks was approximately 850,000 gallons.

The potential risk facing public-water supplies from leaking underground storage tanks is an important concern on Cape Cod, where all water supplies are derived from the sole-source, sand-and-gravel aquifer. The investigation by Gallagher and Steppacher determined that 43 percent of all confirmed spills and leaks of hazardous materials within the $\mathrm{ZOC}$ of the Barnstable well field resulted from leaking underground storage tanks. Furthermore, six confirmed hazardous-waste sites were due to petroleum contamination. A detailed inventory of tanks near one of the Barnstable well sites clearly indicated a potential risk to the water supply from 45 tanks located within $1 / 4 \mathrm{mi}$ of the well site (Gallagher and Steppacher, 1987; p. 32).

This assessment demonstrated an approach for determining the potential risk to quality of water from each tank within the ZOC to a well or well field. The approach, which was assisted greatly by the large data base of tank-characteristic information gathered in the Gallagher and Steppacher study (1987), employed a multicriteria-evaluation model to estimate the risk factor for each tank. All of the tanks within the ZOC were rated, and a list of the tanks and the associated rating was compiled. In the final step, the list was subdivided into four general risk categories ranging from low to high, and a map of the ZOC was prepared showing the locations of tanks, illustrated by a map symbol representing the associated risk category.

The two most important steps in this assessment were (1) calculation of the boundary of the ZOC for a selected well field for this demonstration, and (2) assembly of technical data on tank failure rates related to certain factors. Age, contents, size, and tank construction material were considered in order to devise a simple ranking scheme and it was determined that 

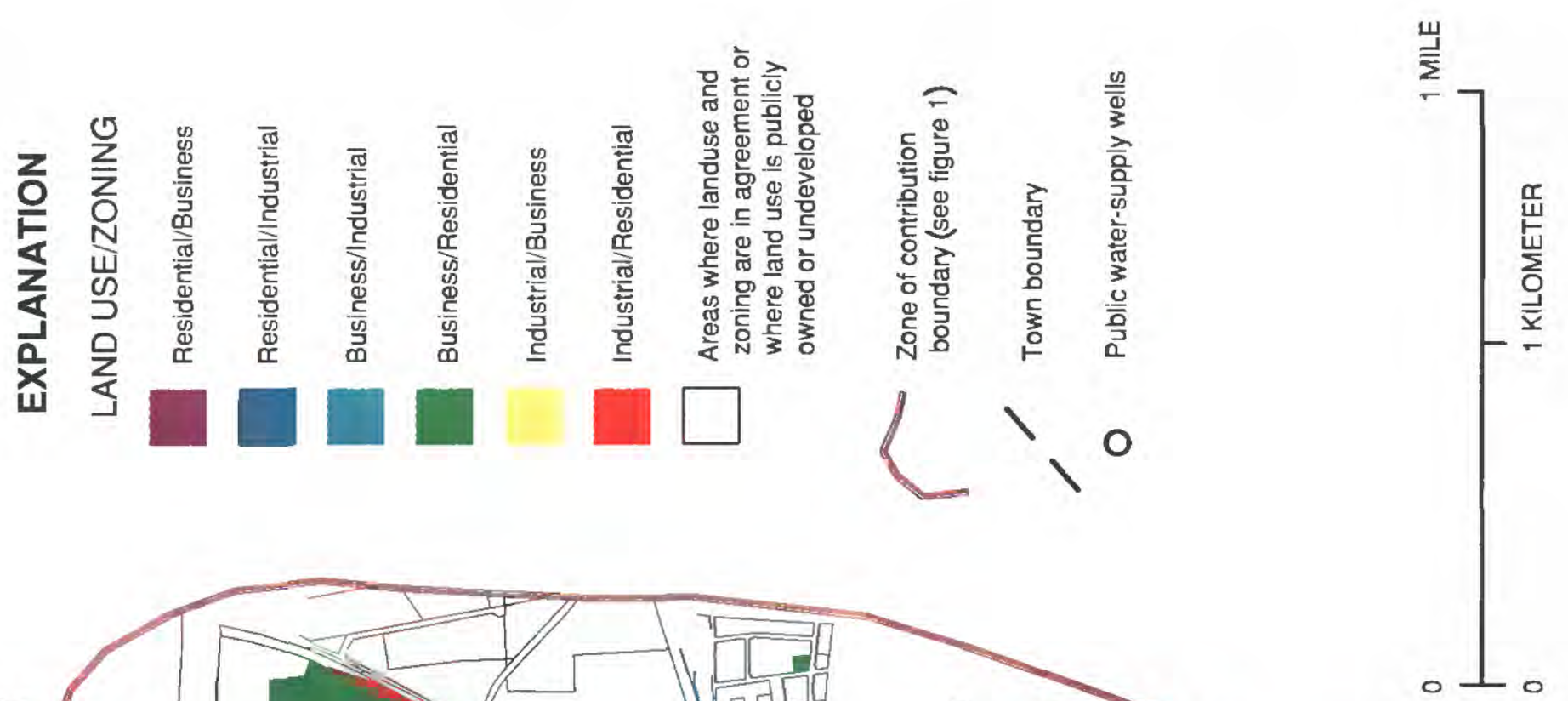

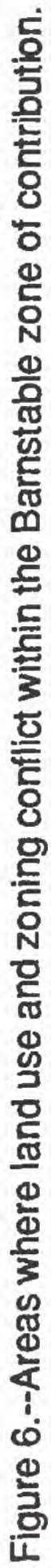


Table 8.--Distribution of land use and zoning in Barnstable and Yarmouth, Massachusetts (1987)

[ZOC, zone of contribution. Values are percentages of total land in ZOC, by land-use and zoning categories]

\begin{tabular}{lcclrr}
\hline $\begin{array}{l}\text { Land-Use } \\
\text { Category }\end{array}$ & Barnstable & Yarmouth & $\begin{array}{l}\text { Zoning } \\
\text { Category }\end{array}$ & Barnstable & Yarmouth \\
\hline Residential & 13.6 & 19.7 & Residential & 17.6 & 65.5 \\
Business & 15.3 & 19.0 & Business & 23.3 & 6.8 \\
Industrial & 23.7 & 8.4 & Industrial & 59.1 & 27.7 \\
Public-owned & 10.9 & 3.7 & & & \\
Undeveloped & 36.5 & 49.1 & & & \\
\hline
\end{tabular}

age of the tanks was the critical factor. In a Maryland tank-testing study (Heck, 1987) tank failure rates and system failure rates were determined to be related to tank age (table 9). A range of values for the tanks was developed in the Barnstable well field ZOC.

Hydrologic data and information on pumping rates were gathered for three Barnstable public-supply wells, A, B, and C, located in the eastern area of the ZOC. By use of the two-dimensional analytical solution by Bear (1979) used in the Eastham assessment, and assuming a pumping rate of $3.12 \mathrm{ft}^{3} / \mathrm{s}$, an average horizontal hydraulic conductivity of $250 \mathrm{ft} / \mathrm{d}$, and a porosity of 0.35 , the dimensions of the $\mathrm{ZOC}$ were calculated for the center of the well field. A watertable map of the area was used to orient the ZOC boundary with respect to the principal direction of ground-water flow, and an end line was drawn on the $\mathrm{ZOC}$ at a distance approximately equivalent to a 5 - year time-of-travel, so that the ZOC could be analyzed as an area (fig. 7).

Neither the purpose of this study nor the short project timetable permitted the derivation of a quantitative risk-ranking scheme for this assessment. An evaluation of the range of values for each tank characteristic was made, and published information from underground tank studies was used to assign a single numerical value ranging from zero to six to the characteristics of each tank.

The Maryland data were used to divide the tank ages into seven age ranges and to assign a risk rank to each range. The higher the tank age, the higher the numerical rank (i.e., the higher the risk of tank failure that would increase the risk of ground-water contamination). The risk-ranking scheme was then applied to all of the tanks within the well field ZOC.

Table 9.--Ranking factors used to describe the relation between tank failure rate and tank age ${ }^{2}$

\begin{tabular}{lccc}
\hline $\begin{array}{c}\text { Age } \\
\text { (years) }\end{array}$ & $\begin{array}{c}\text { Tank fallure rate } \\
\text { (percent) }\end{array}$ & $\begin{array}{c}\text { System fallure rate } \\
\text { (percent) }\end{array}$ & $\begin{array}{c}\text { Numerical rank } \\
\text { used In this study }\end{array}$ \\
\hline $0-4$ & 0 & 0 & 0 \\
$5-9$ & 0 & 0 & 1 \\
$10-14$ & 17 & 33 & 2 \\
$15-20$ & 9 & 37 & 3 \\
$21-25$ & 5 & 39 & 4 \\
$26-30$ & 11 & 49 & 5 \\
$31+$ & 25 & 42 & 6 \\
\hline
\end{tabular}

${ }^{2}$ Tank-age and failure-rate data from Heck (1987) 


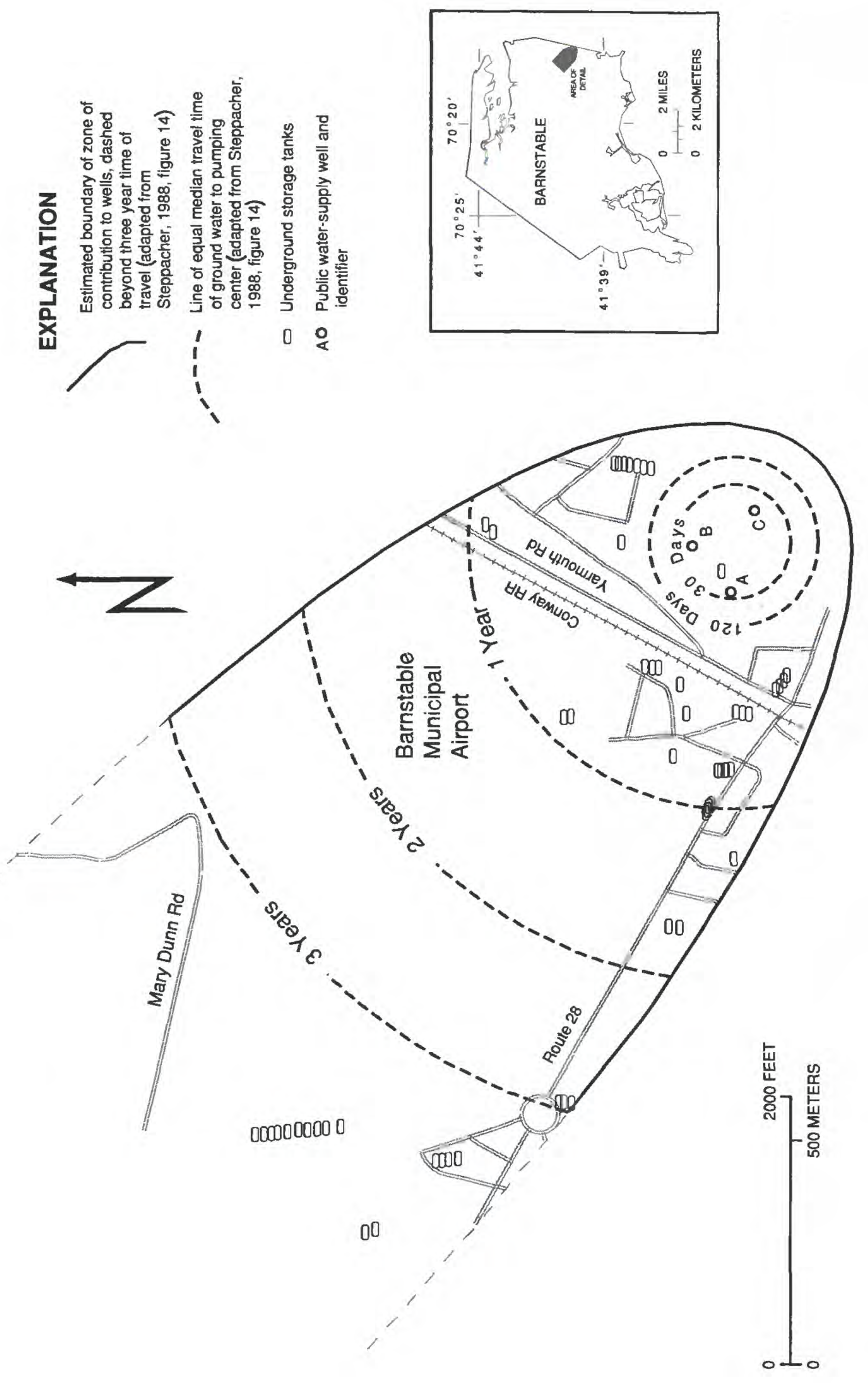

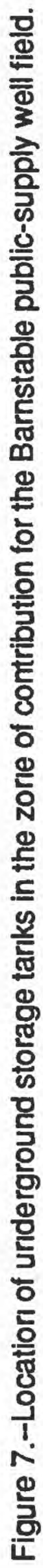


In addition to age, five other tank characteristics were evaluated and their range of values ranked according to published information or best judgment (fig. 8). Tank contents were evaluated and ranked on biodegradation potential using published data: least degradable contents equals highest rank (U.S. Environmental Protection Agency, 1985, p. 9-4). Tank distance from the center of the Barnstable well field was determined from a ranking of time-of-travel data estimated from flow-net analysis provided by the Bear (1979) ZOC determination (shortest distance equals highest rank).

Rankings for tank material (most susceptible to corrosion or rupture equals highest rank), tank size (largest tank equals highest rank) were derived using best judgment. The potential for tank failure from structural loading of buildings and roadways was ranked on a basis of land use about the tank. Tanks in residentially zoned areas were considered to be at lowest risk. Conversely, tanks in business and highway/business zones--such as small parcels used for gasoline-pumping stations--were considered to be at highest risk.

The steps for this assessment are listed in table 10. A computer program of the multicriteria-evaluation model was prepared. The model evaluated the range of characteristic values for the tanks within the ZOC, assigned numerical ranking values for each characteristic, summed the six values for each tank, assembled them in ascending numerical order, converted these values to percentage of total possible score, and assigned a risk category ranging from low to high for each tank according to the ranges of scores for low to moderate (40 or less), moderate (41 to 60 ), high to moderate (61 to 80 ), and high ( 81 or higher).

The result of this assessment was a map of the ZOC of the Barnstable well field showing the locations of the underground storage tanks--illustrated to indicate their relative risk to the wells (fig. 9).

The most important outcome of this undergroundstorage-tank analysis was its ability to demonstrate a step-by-step approach for assessing total risk owing to the physical characteristics of the tanks, the tank contents, and tank locations within the ZOC. The pilot nature of this study and the lack of local technical data on tank failure rates precluded the derivation of an accurate, proven risk model for the project area. If few technical data are available on underground tank failures, reason dictates the use of qualitative means, such as the selected automated multicriteria-evaluation model used in this study. Modifications to the numerical ranking schemes or to the criteria used can be made quickly, and risk assessments can be recalculated efficiently and easily. The rapid query, analysis, and display capability allows evaluation of many different types of water-quality risks and risk-abatement alternatives.

\section{Modeling Nitrate Concentration in Ground Water at Public-Supply Wells}

One of the technical tools that resulted from the CCAMP study was the development of a water-quality model for predicting nitrate concentration in ground water (Frimpter and others, 1988). The model, which is based on a mass-balance concept, assigns a specific nitrate load to each nitrogen source. The model calculates the nitrate concentration in well water from the total load of nitrogen and the total volume of water contributed to the well under steady-state conditions.

The step-by-step approach (table 11) concentrated on converting the water-quality model into a program that could be used within the GIS data base. The first step in the GIS program was to condense more than 100 land uses into 12 representative categories. Nitrate-loading factors were assigned to each of 12 representative land uses. The program scanned the Barnstable parcel-map data base, identifying the type of land use in each parcel, converted the land use to one of the 12 representative categories, and assigned the nitrate-loading factor. The dissolved nitrate as $\mathrm{N}$ load was calculated for each parcel, and the water-return volume and load of nitrate for all parcels was calculated and summed. In the final program step, the total nitrate load was divided by the total water volume to derive a nitrate concentration in the well.

The result of this assessment was a parcel map of the Barnstable ZOC showing the source areas for nitrate loading to the ground water and the relative magnitude of loading (fig. 10). The GIS nitrate-model program assigned water-return flows and nitrate loads to 1,928 land parcels in the 12 land-use categories. A total return flow of $9,134,500 \mathrm{~L} / \mathrm{d}$ (liters per day) and a total load of $205,047,600 \mathrm{mg} / \mathrm{d}$ (milligrams per day) of nitrate as nitrogen were combined with recharge from precipitation to estimate nitrate concentration in well water. Assuming a withdrawal rate of $8 \mathrm{Mg} / \mathrm{d}$ or $30,280,000 \mathrm{~L} / \mathrm{d}$, the mass balance calculation of nitrate concentration in well water is $6.8 \mathrm{mg} / \mathrm{L}$ (milligrams per liter). 
Risk Summary

Ranking of Tank Characteristics

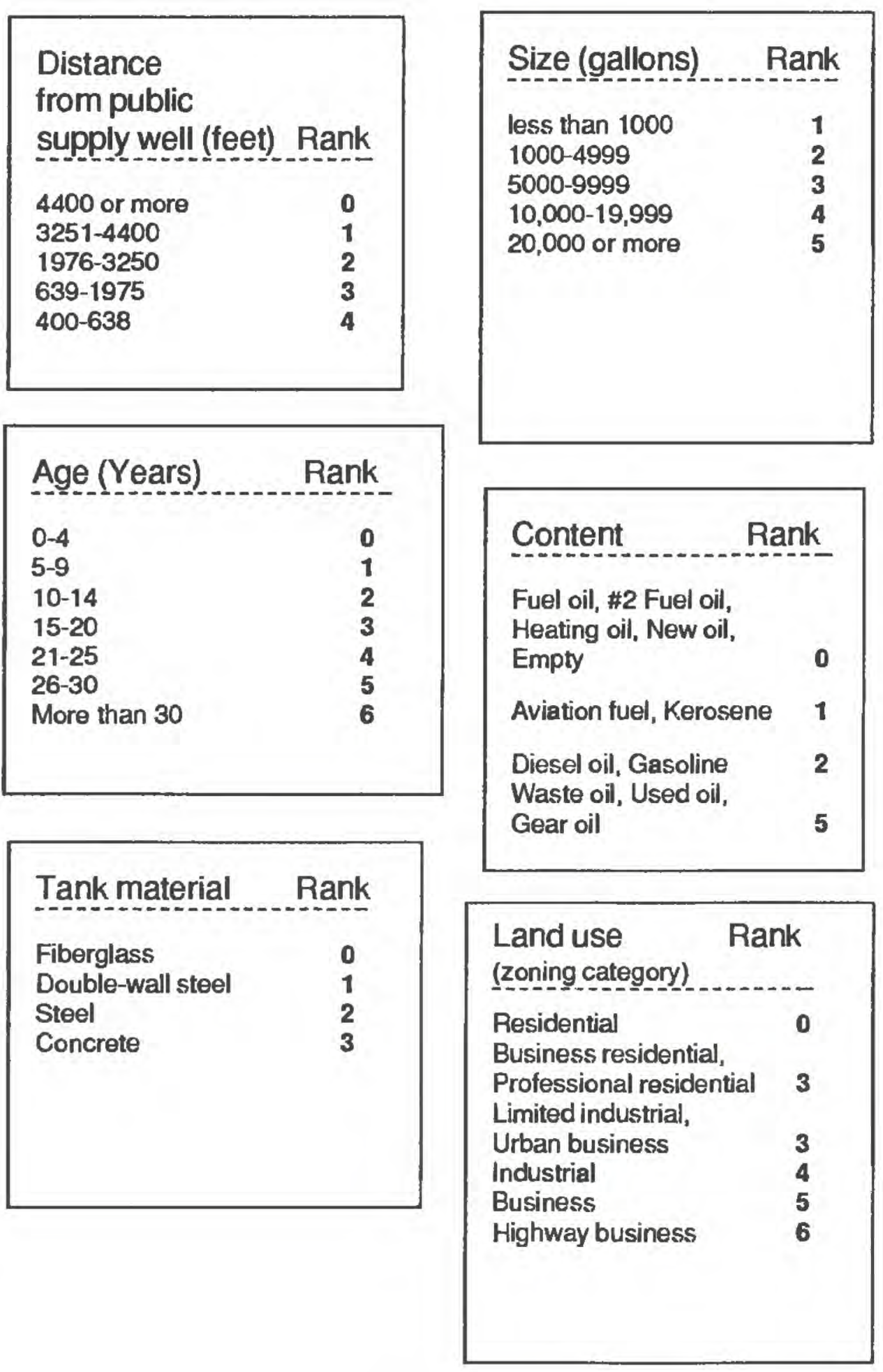

Notes: This illustration presents the results of one type of a multicriteria evaluation method to estimate the risk that underground storage tanks pose to ground-water quality at a public water-supply well. In an automated procedure, the range of values for six characteristics of each tank located within the zone of contribution to a well are ranked and then added to determine the risk from the tank. The data for this demonstration in the Barnstable zone of contribution were compiled in January 1987 by the Cape Cod Aquifer Management Project (CCAMP). This analysis is one of six demonstration assessments prepared by the CCAMP-Geographic Information System project.

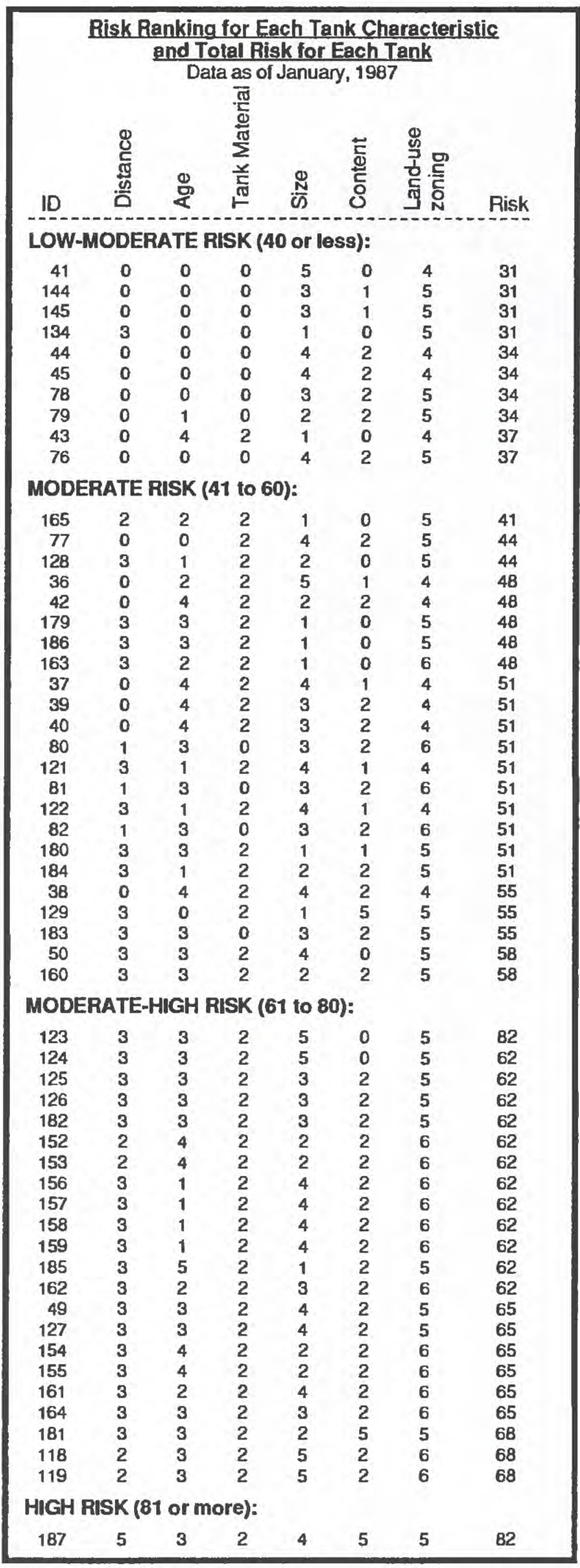

Figure 8.--Underground storage tank characteristics, ranking factors, and summary list of qualitative risk to water quality at public-supply wells within the Barnstable well A zone of contribution. 
The CCAMP Aquifer Assessment Group also applied the mass-balance nitrate loading formula to publicsupply wells in the same zone of contribution (Gabrielle Belfit, Cape Cod Planning and Economic Development Commission, 1989, written commun.) In their analysis, a detailed parcel-by-parcel inventory of sources was made from Board of Health files to determine seats per restaurant and number of rooms per motel. Estimates of loads were also tallied from State wastewater-discharge permits (volumes greater than 15,000 gallons per day). Employee numbers for small businesses were determined from records of the Massachusetts Department of Employment Security to estimate septic system loads from businesses. Additional building size information used for estimating loads for individual parcels was obtained from town tax assessors records and from a telephone survey of gas stations and beauty parlors. Calculation of nitrate concentration in well water within this detailed parcel-by-parcel inventory resulted in an estimate of $8.6 \mathrm{mg} / \mathrm{L}$.

The two estimates are in fairly close agreement. They both violate a $5-\mathrm{mg} / \mathrm{L}$ planning goal for nitrate concentration and conform to the USEPA $10-\mathrm{mg} / \mathrm{L}$ for drinking-water regulation. First, the number of land parcels and loading units differed; 354 was used by the Aquifer Assessment Group and 655 in the GIS analysis. Second, the Aquifer Assessment Group identified and differentiated multiple land uses within the same parcel and calculated multiple loads for individual parcels. In the GIS analysis, only one load was calculated on the basis of one land use. The Aquifer Assessment Group used a withdrawal rate of

Table 10.--Step-by-step approach for estimating risk to a public-supply well from underground storage tanks within the zone of contribution

[ZOC, zone of contribution]

Assessment

Risk to ground-water quality from underground storage tanks
Comments

\section{Step-by-Step Approach}

1. Calculate the dimensions of the $Z O C$ for an individual pumping well or well field and use water-table maps to orient $\mathrm{ZOC}$ on map of the area.
Delineate the area of risk from storage tanks.
2. Compile data on the location and physical characteristics of the tanks in the ZOC.

3. Use available technical data to devise a numerical ranking scheme for the range of observed tank characteristics, in an order consistent with increasing sources of potential contamination to water quality.

4. Use the ratings scheme and the real tank characteristics to rate each characteristic of each tank.

5. Sum the characteristics for each tank and compile a list of tanks in order of ascending rank.

6. Normalize the range of rank values, divide the range into selected brackets, and assign a risk category to each bracket.
Data will be used for evaluating the range of values and assigning.

A simple, unweighted additive model will be used to calculate a a single risk value for each tank. The value is the sum of the ratings value assigned to each characteristic of the tank.
7. Prepare a map and summary tables of the well, the ZOC area, and the tank locations--illustrated with different symbols to indicate their risk category.
Any method can be used to divide the range of rank values into brackets and assign risk categories from low to high. 

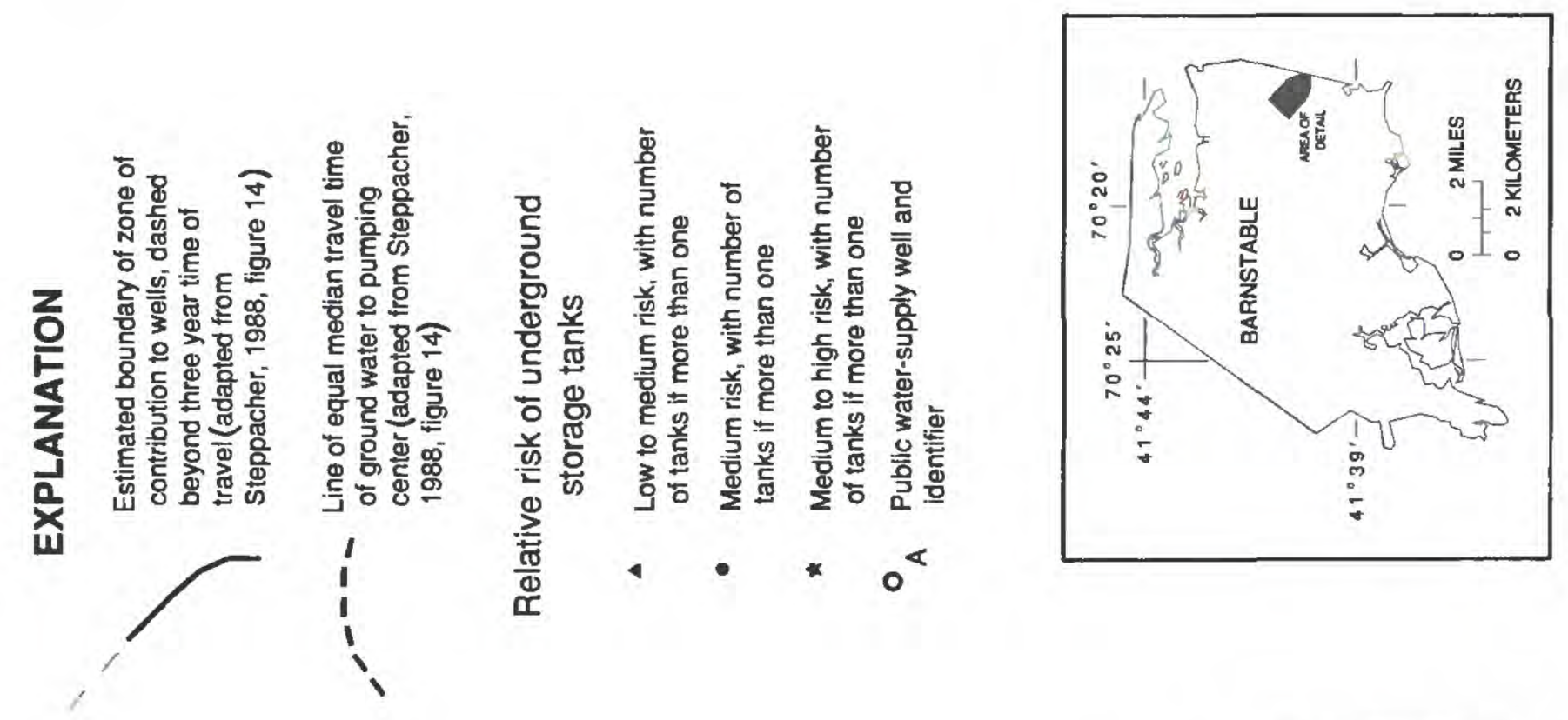

$\stackrel{\mathscr{2}}{2}$

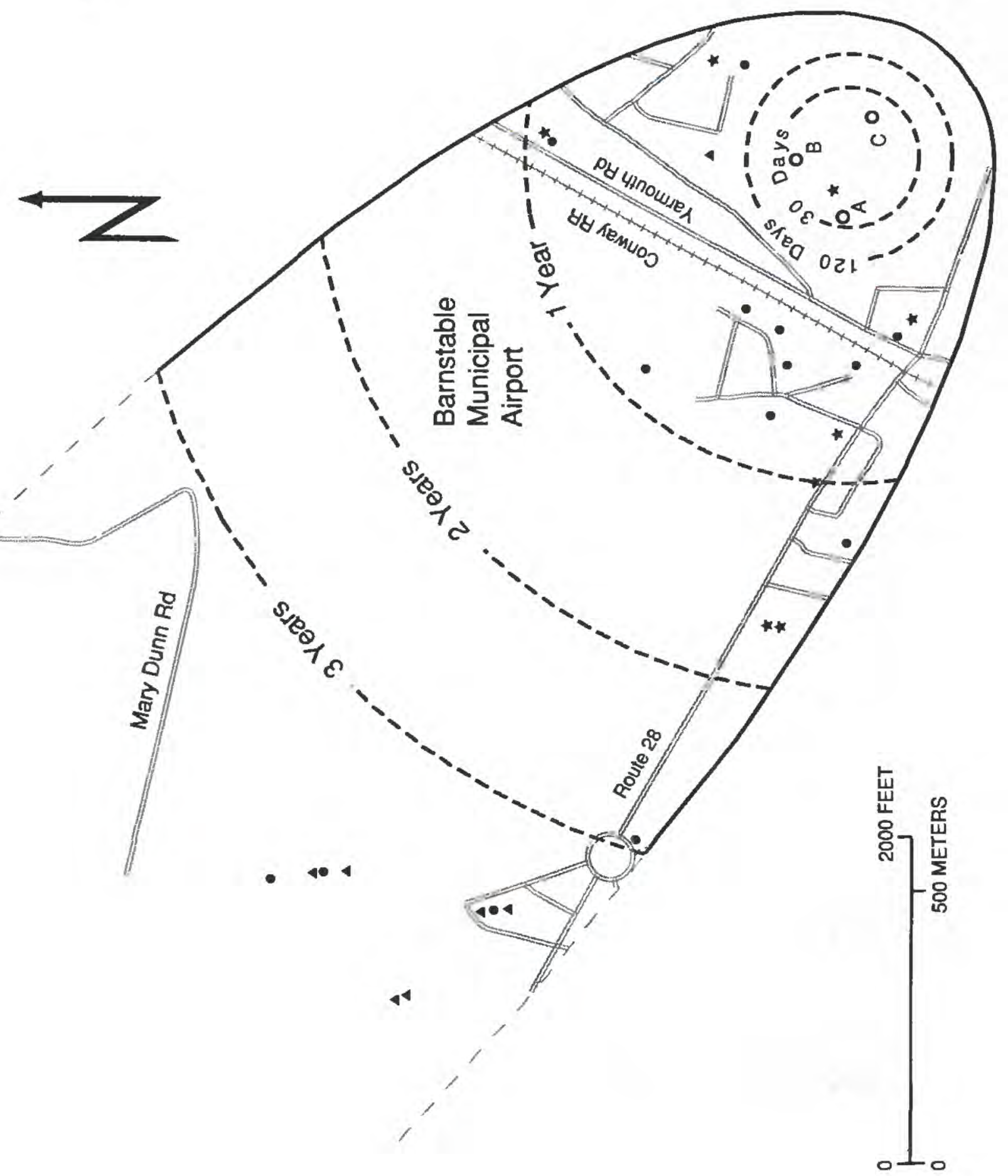

잉 
$7.8 \mathrm{Mgal} / \mathrm{d}$, and the GIS analysis used $8 \mathrm{Mgal} / \mathrm{d}$; as a result, dilution of nitrate load was greater in the GIS analysis compared to that calculated by the Aquifer Assessment Group.

The most important result of this assessment was the illustration of the uses of a GIS to depict variable nitrate-load patterns within the Barnstable well field ZOC and automated inclusion of the analytical nitrate model into the GIS. Together, the models can be used to simulate alternative loading formulas and development scenarios.

\section{Risk to Ground-Water Quality from Landfills}

There are approximately 25 active landfills on Cape Cod, and ground-water contamination is present in the 15 landfills that have been tested (Zoto and Gallagher, 1988; p. 12). The majority of landfills are located away from populated coastal areas in the central part of Cape Cod where the most important ground-water recharge areas are located. However, the sources of potential contamination to groundwater quality at public-supply sites throughout Cape Cod is very great because at least 10 landfills are located either within or upgradient from mapped zones of contribution (fig. 11). Many other landfills are located in areas that otherwise might be suitable for water-supply development. In most cases, the landfills not only are sources of potential contamination to the quality of ground water at public-supply sites, but at private-supply sites also.

When the CCAMP study began, the MDEP landfill program was rapidly increasing regulatory and enforcement efforts to manage and clean up landfills.

Table 11.--Step-by-step approach for calculating nitrate concentration in well water [ZOC, zone of contribution; GIS, Geographic Information System]

\begin{tabular}{ll} 
Assessment & Step-by-Step Approach \\
\hline $\begin{array}{l}\text { Modeling } \\
\text { nitrate }\end{array}$ & 1. $\begin{array}{l}\text { Obtain the water-quality model and } \\
\text { prepare a GIS-program version, } \\
\text { concentration }\end{array}$ \\
following steps 2-6.
\end{tabular}

in publicsupply well water.
Comments

Convert the analytical model to a program that could access the GIS data base and perform the calculations.

2. Condense all potential land-use categories into 12 land uses.

Nitrate loading factors are not available for every type of land use.

3. Assign nitrate-loading factors to the 12 From Frimpter and others (1988). types of land use.

4. Scan land uses for all parcels within the $\mathrm{ZOC}$, determine representative type of use, and assign nitrate-loading factors.

5. Calculate dissolved nitrate load based on number of bedrooms, square footage of land, number of restaurant seats, number of gasoline islands, and other such factors, for each parcel and sum the total volume and total nitrate load for all parcels in the ZOC.

6. Divide the total nitrate load by the total volume to derive the nitrate concentration in ground water.

7. Prepare a map of land parcels in the ZOC showing nitrate sources and relative strengths. Tabulate data on total volumes and loads.
Identify parcels contributing nitrate loads to ground water and tabulate results of calculations. 


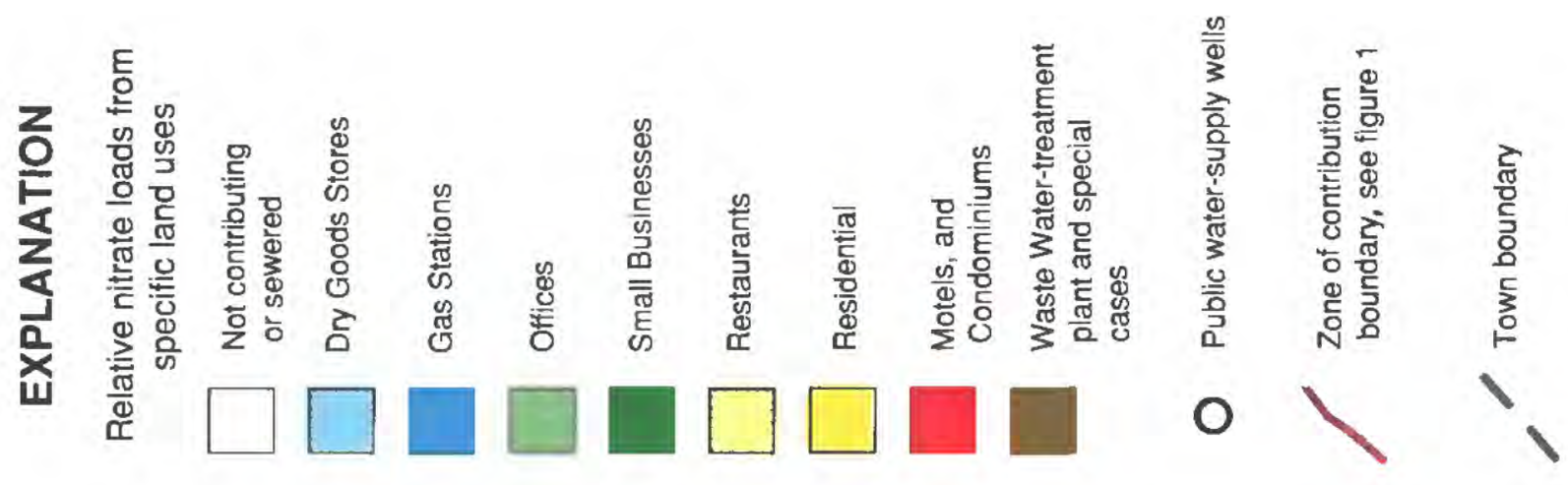

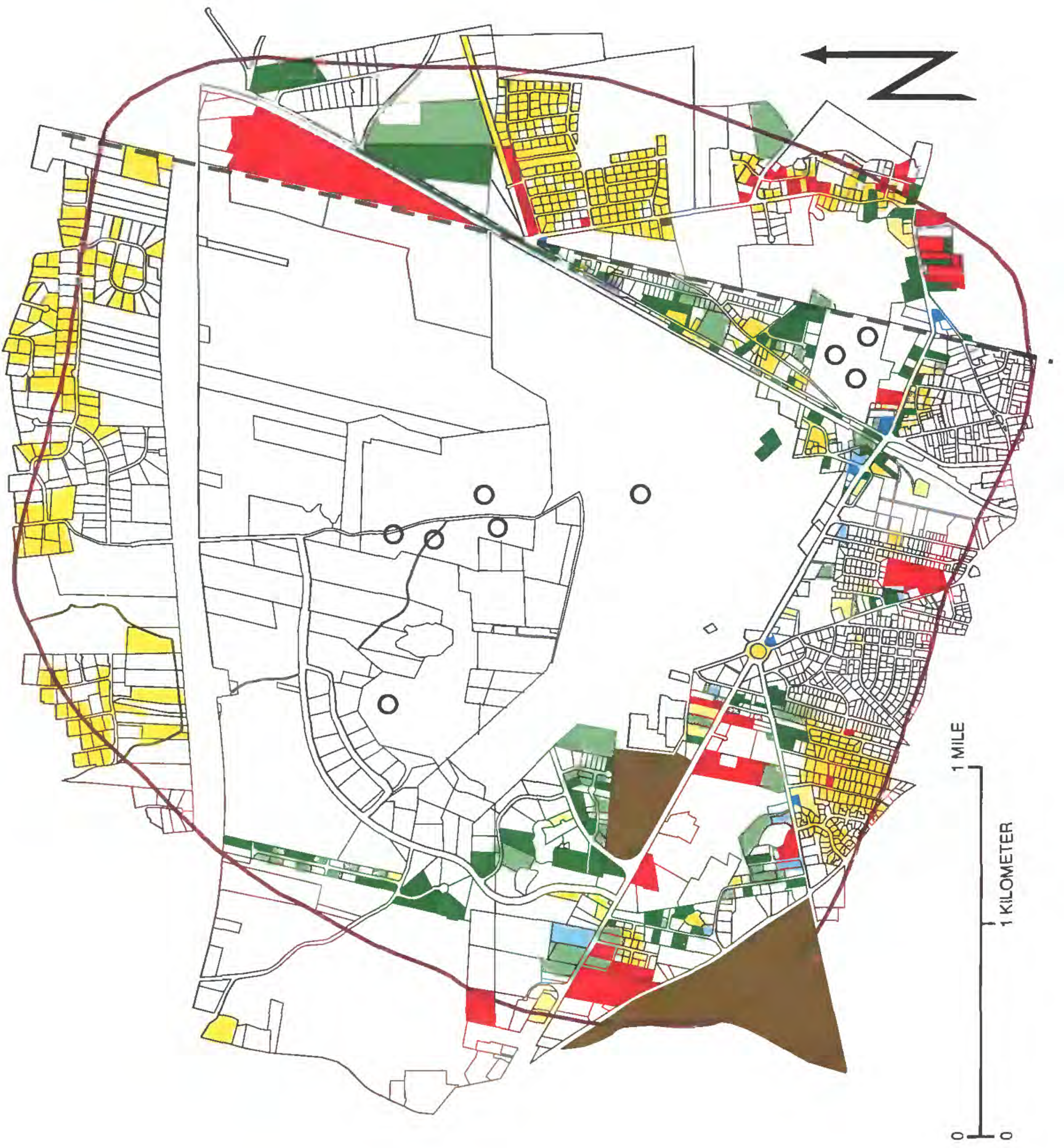




\section{EXPLANATION}

Calculated zone of contribution

\section{— - Town boundaries}

Location and potential risk of landfills to public-supply wells

$\square$ Moderate risk

( Moderate to high risk

High risk

- Public water-supply wells
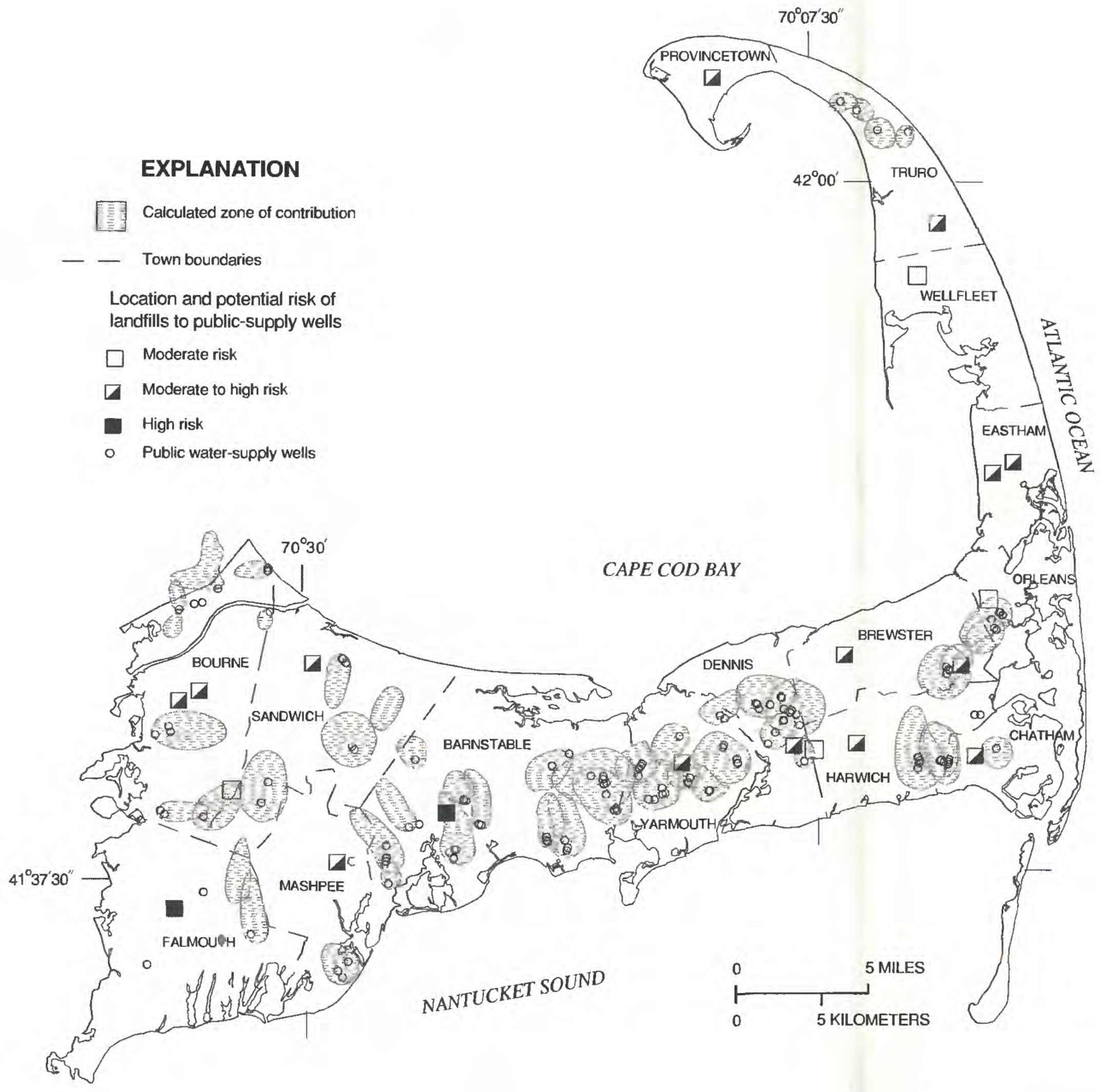

Figure 11.--Locations of public-supply wells, zones of contribution, and landfills, Cape Cod, Massachusetts (1987). 
The amount of technical effort that was required to implement the program far outstripped the States' available resources. However, the CCAMP team recognized that GIS could be used to demonstrate relatively efficient methods for making initial evaluations of the sources of potential contamination to publicwater-supply sites from landfills. A ranking scheme was developed that evaluated hydrogeologic and landfill characteristics and prioritized potential risk.

The step-by-step approach (table 12) began with the development of a ranking scheme based on seven characteristics that affect the potential for landfill leachate to contaminate ground water. LeGrand ranking factors (1983) were used to rank most characteristics, including depth to water table, water-table gradient, and the nature and thickness of the unconsolidated material near the landfill. Additional landfill characteristics included in the ranking scheme were landfill size, the presence of a liner and leachate-collection system, and the distance between the landfill and the ZOC boundary (fig. 12).

Distance was considered to be a major factor controlling the potential for contamination of ground water by a landfill in a ZOC and, therefore, was weighted most heavily of all characteristics. In cases where landfills are already located within a ZOC, the landfill was automatically categorized as moderate-to-high or high risk, and the ranking calculation was not performed. The ranking of risk from landfills is illustrated in figure 12 .

Weighted numerical rankings for each landfill were obtained by multiplying the rank of each of the seven landfill characteristics by its weighting factor and summing the results. The weighted numerical rankings were standardized as a percentage of total possible score and listed in ascending order. Finally, the risk rankings were divided into ranges and a general risk category, from low to high, was assigned to each

Table 12.--Step-by-step approach for assessing risk to public-supply sites from landfills

[ZOC, zone of contribution]

Assessment

Risk to ground-water quality from

landfills

\section{Comments}

Step-by-Step Approach

1. Overlay the locations of public-supply wells, landfills, and ZOCs on a map of Cape Cod.
Start by illustrating the spatial relations between wells and landfills.

Determine the most important characteristics of landfill sites that affect the sources of potential contamination to water quality.

Some characteristics, for example distance from the landfill to the well, are considered to be more important than others.

Landfills located within ZOCs are automatically given a moderate-tohigh or high-risk category.

5. Standardize the landfill ranking values and list in ascending order.

6. Divide the ranked values into ranges and assign a risk category to each range.

7. Prepare map of Cape Cod showing well sites, ZOCs, and landfills-illustrated with different symbols to indicate their risk category. Include tabular information on ranking factors and final risk ratings. 

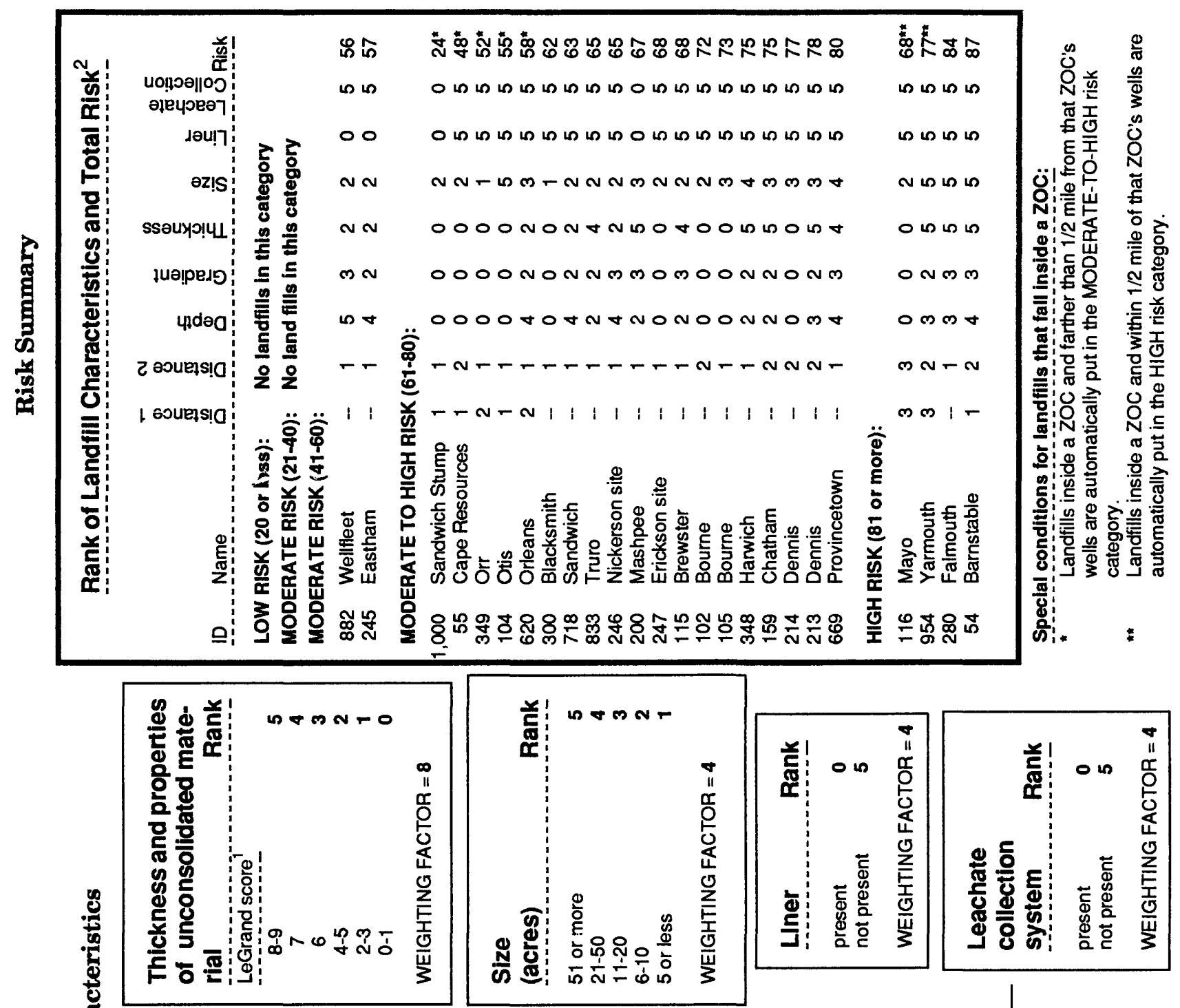

䞡
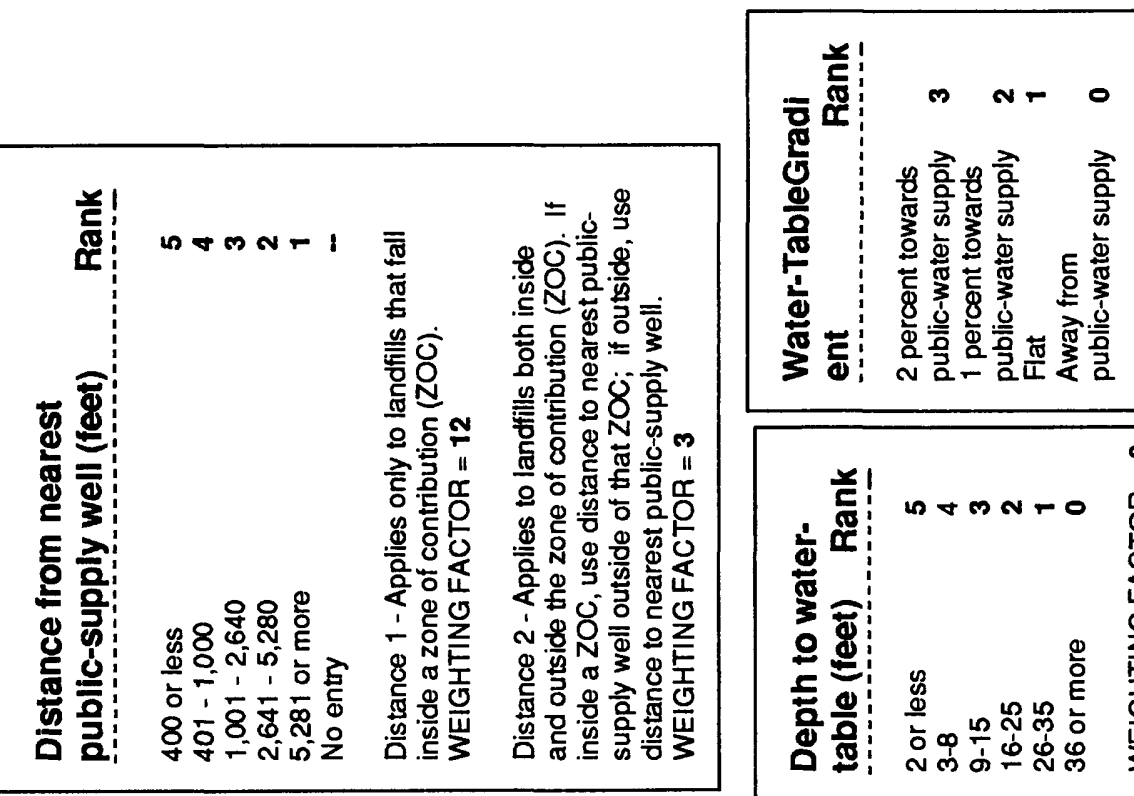
range. The result was a list of landfills in order of increasing potential sources of potential contamination to ground-water quality at public-water-supply sites. The landfills--illustrated with different symbols to indicate their risk category, the wells and their ZOCs are shown in figure 11.

The landfill assessment was the only regional example of risk assessment completed during this study. The ranking scheme used in this example was intended to demonstrate how the step-by-step screening process worked when deriving a solution involving a diversity of information. The LeGrand ranking factors, which have been used in many applications, are described in technical literature as well as in this study, and are based on important, well-known hydrogeologic and landfill characteristics. When State and regional planning agencies begin using automated methods for planning, regulatory, and enforcement efforts at landfills, they can use ranking factors and weighting schemes that are specific to the physical characteristics of the region and the landfills.

\section{LESSONS LEARNED}

In addition to providing examples of how to assess the risk to water quality at public-supply wells on Cape Cod on a regional and local scale, an important goal of this project was to document the lessons learned in conducting the project. Problems identified during the study are identified in bold italics in the following text. The following discussion identifies and addresses the key technical and administrative issues that were encountered in assembling and working with data, identifying problems, devising solutions, involving decisionmakers, using a team approach, and managing project timetables.

1. General problems with the basic data. With the exception of the USGS's 7-1/2-minute quadrangle maps and the 1:7,200 base maps provided by the town of Barnstable Planning Office, the quality of base maps used for establishing digital cartographic base maps for Eastham and parts of Barnstable and Yarmouth was relatively poor. Many maps containing important information were printed on paper rather than on scale-stable material, and it was not uncommon for original source maps or one-of-a-kind maps to be worn out, torn, or wrinkled. Although these maps convey information pertinent for analysis, the inaccuracies introduced into the digital data base because of their condition created ongoing problems. Shrinkage, stretching, wrinkling, tearing, taping, and the use of multiple-generation photocopied originals often required adjustments as the base maps were digitized.

Despite the problems with low-quality base maps, many maps were digitized and digital base maps that matched real geographic features were produced. Only the best-quality base maps available were sought out; poor-quality maps were adjusted before and after digitizing only if absolutely necessary.

Although the project benefited from an unusually large amount of available map and tabular data, many data were not geographically referenced. Many maps were constructed without registration to a cartographic projection or a coordinate system. This made it difficult to register base-map information to geographic coordinates. Lack of geographic-reference information also was common to tabular data bases made available to the project. Several data bases, either in paper or digital format, thought to be useful for risk assessment by the CCAMP study team were evaluated. SPOT, remotely sensed land-use information and RTK, an inventory of businesses required to inform employees of potential toxic and hazardous material exposure in the workplace were geographically referenced by street address. UST, an inventory of underground storage tanks; TOX, an inventory of toxic and hazardous materials; SQG, an inventory of small quantity generators of toxic and hazardous materials; FINDS, an inventory of facilities as potential sources of pollution, and NONCOM, an inventory of noncommunity water supply wells in Eastham, were geographically referenced with a land-parcel identification number. Neither type of locational reference could be used when converting to a GIS data base. The lesson learned was that the availability of tabular data in digital format was not necessarily an advantage. Data were difficult to convert without a geographic location--such as latitudinal and longitudinal coordinates--or contain a reference in the data file that could be related to another data base that was geographically referenced.

Duplicate versions of data were often encountered during the study. There were different versions of the same data because some State and regional agencies collect and store the same types of data (for example, public-supply well sites), and because verification efforts by a number of team members sometimes resulted in multiple copies and updated versions of the same information. Through field surveys, CCAMP team members cross referenced the original street addresses in the RTK data base to land-parcels. The 
relational data base associated with the Barnstable town-parcel map included information on a large number of potential contamination-related activities (TOX, SQG, FINDS, UST, RTK, and NO3--a parcel by parcel estimate of nitrate loading from waste water and fertilizer developed by CCAMP team members), and project experience indicated that this type of data base required careful updating to minimize multiple copies. Because multiple-agency data bases were used, a substantial amount of effort was required to resolve discrepancies on location, well identification, and other well characteristics. Though most problems with duplication of data could be resolved with additional resources and effort, obtaining data from many agencies requires significant cooperation between Federal, State, and regional agencies.

The need to document data was realized early in the study. A document describing the data bases created during a study--herein referred to as a Data Dictionary (Appendix A), is important to provide background information on the source, scale, and accuracy of the original data. Additional helpful information could include a description of the quality of the source maps or tabular information, and lists of contact-persons available for answering questions and describing data revisions that may have been made. Data should be documented during production rather than after the study has ended; at the conclusion of the study, the Data Dictionary can become a users' manual of the data base for future use.

Many data scale and accuracy issues had to be resolved during the project, particularly during the later stages of the project when analyses were complete and it was necessary to describe the accuracy of the final results. Scale and accuracy issues are common to all projects but are especially obvious in projects that use GIS technology. Few GIS studies are supported by data bases that are all of the same scale and accuracy. And, as in most studies, the scale of the problem defines the scale and the accuracy of the solution.

This project used data representative of a wide variety of scales and accuracies without substantial negative consequences. A key to using information from different sources, scales, and accuracies is to provide a description of the data used in the description of final study results, and to ascribe the accuracy of the final results to that of the smallest-scale, least-accurate data used in the analysis.

Finally, too much data were gathered during this study. When data analysis was completed, it was concluded that too much time was spent collecting data that were readily available but never used in the assessments. More analyses could have been performed with fewer, more relevant data.

2. Specific problems with the basic data. Three agencies supplied information on the location and characteristics of public water-supply wells. USGS's State Water Use Data System (SWUDS) data base, MDEP's Water Supply Protection Atlas, and CCC files were the source of the well data. Many major discrepancies in fundamental information such as location, name, identification number and well characteristics were found to exist between the data bases. After considerable evaluation and debate, it was resolved to use the SWUDS data base, verified by MDEP staff, for the analyses in this study.

Many problems common to the development of a digital base map were experienced in creating the Barnstable digital base. Parcel data were digitized from town tax assessor's parcel maps that were not documented with geographic reference points, a map projection, or an accurate scale. Original tax assessors' maps were made of paper, photocopied from other sources, and physically worn. A mylar version of the Barnstable base map was made from the assessors' maps that had been photoreduced and spliced with tape. In some instances, the mylar map did not match the original assessors' maps. Because the Barnstable and Yarmouth town tax assessor's maps were produced differently, they did not fit together, and a computer scale-changing process was used to improve the fit.

The land-use data that were related to the town parcel digital base map required careful checking. The timetable of the project restricted the complete checking of the information and updates as they occurred. One of the most important restrictions was the assignment of one land use per land parcel. In the Barnstable ZOC, a number of parcels have more than one land use. This limitation affected assessments in the nitrate-modeling analysis that relied heavily on the accuracy and completeness of land-use information. Inaccuracies introduced by assigning one land use to land parcels become particularly misleading when the parcels are large, the sources small, and their location within the parcel unknown.

Although the private-well data base for Eastham was not used extensively in the Eastham well-siting assessment, the data base presented a series of problems that provided insight that could aid future efforts to gather and store this type of information. The data 
base consists of location and characteristic information, including water-quality data on approximately 1,300 private wells. In some instances, the data were incomplete. Some locational data had no information on characteristics such as identification number or name. In other cases, identification numbers and water-quality data were not referenced to a geographic location. One drawback was that the tabular data base was found to contain multiple entries for the same well and did not contain unique identification numbers. Many of these problems were not resolved during this project. However, efforts to convert the data into a GIS data base indicated that most of the problems with the existing data base could be overcome with additional data collection and field verification.

3. Problem definition and objectives. For the CCAMP team, it was tempting to become involved in GIS data compilation, preliminary overlay analysis, and graphical display before having a firm understanding of the problem and objectives of an assessment. This is not necessarily a problem unique to GIS-based projects. A basic rule applied during this study was, "do not perform data analysis and assessment development until the problem and the objectives of the study are defined."

\section{Develop GIS methods for solving the problem.} A method was needed to meet the objectives of each assessment. This study depended on a storyboard approach to identify data needed for analysis, conceptualize the step-by-step approach, and manage the overlay and analysis process. This method helped to manage a large amount of complex information and compose assessments in a relatively small number of steps without wasting a large amount of time and effort on overlaying and displaying unneeded combinations of data.

5. Involve decision makers. To include policy and decision makers early in the GIS project process, a few initial base map and technical data bases were developed and distributed. Because rapid data query, compilation, and overlay began with relatively few data, policy and decision makers were brought into the early stages of the study to observe preliminary results, contribute insight to identifying study goals and solutions to problems, and guide preparation of final map products. Therefore, upper-level managers and administrators did not have to wait for the completion of staff-level tasks. The involvement of experienced, senior-level managers and policy makers throughout the project could mean the difference between a successful and an extraordinary product.

6. Use a project team. The project team was composed of an interdisciplinary staff. Each participant brought to the team a unique technical experience and point of view representative of the respective agency. A large amount of data was gathered quickly and extra efforts to verify information were made. However, a lesson learned in this study was to keep the number of part-time team members to a minimum. Part-time staff are helpful, but large amounts of time can be taken up in keeping these staff members informed of project progress and developments that occurred during their absence.

7. Plan the timetable carefully. This study demonstrated that a short-term, 9-month GIS study can be completed successfully and within deadlines and within budget. However, experienced staff and adequate available data are a prerequisite. The need to plan a large amount of time for gathering data, including a firm deadline for stopping data collection, is an important requirement of a project timetable. Allowance of as much time as possible for data analysis also is a key factor.

\section{SUMMARY AND CONCLUSIONS}

Methods for assessing risks to ground-water quality at public-water-supply wells on Cape Cod, Massachusetts, were demonstrated in a 9-month project. Data analyses were guided by the technical, management, and institutional issues identified on Cape Cod by the Cape Cod Aquifer Management Project (CCAMP) 2year collaborative effort by Federal, State, regional, and local government agencies.

The project was conducted by an interdisciplinary team of staff members from the U.S. Geological Survey, U.S. Environmental Protection Agency, Massachusetts Department of Environmental Protection, and Cape Cod Commission. Efforts concentrated on developing methods for assessing risk from individual contamination sources within the zone of contribution to water-supply wells. The use of a Geographic Information System (GIS) technology made it possible to store, manipulate, and analyze information from more than 30 data bases for Cape Cod and the towns of Barnstable and Eastham.

Because of the demonstration nature of this project, three representative situations were selected for anal- 
ysis: (1) The ZOC of one hypothetical public-supply well anticipated for the rural, seasonally populated town of Eastham, Mass., (2) the composite ZOC for nine public-supply wells within the urbanized town of Barnstable, Mass., and (3) the ZOCs for Cape Cod Peninsula. The three areas were chosen because they provided opportunities to help solve several current environmental problems, including siting of future wells to minimize risk from potential contamination sources (Eastham) assessment of risk to wells from existing sources within a ZOC (Barnstable) and assessment of risk to wells from sources within and upgradient from ZOCs (Capewide).

Six assessments were made to demonstrate methods for assessing risk to ground-water quality: (1) siting of potential public water-supply wells, (2) potential risk from land-use changes, (3) intertown management--zones of contribution across town boundaries, (4) risk to ground-water quality from underground storage tanks, (5) nitrate concentration in public-supply well water, and (6) risk to ground-water quality from landfills. One of the most important results of the selected assessments was the development of stepby-step methods composed of data-overlay and buffering techniques for evaluating these different types of water-quality issues.

The Eastham well-siting analysis demonstrated a method of combining information on land parcels, roads, ponds, and wetlands with examples of estimated ZOC areas for a 1-Mgal/d public-supply well to serve as a screening process for identifying potential water-supply sites. In the Barnstable ZOC, the potential increases in sources of potential contamination to ground-water quality from the hypothetical development of available lands were evaluated by use of land-use and zoning data gathered in the vicinity of pumped supply wells. The Barnstable ZOC includes part of the adjacent town of Yarmouth. The need for close intertown and intratown coordination of groundwater-protection efforts was illustrated by a review of the land-use and zoning maps for each town and the identification of areas within the $\mathrm{ZOC}$ where nonconforming uses in neighboring towns could jeopardize water-quality protection plans.

Land-use data also played an important role in the results of an analysis of nitrate concentrations in ground water analysis developed from a CCAMP model by Frimpter and others (1988). A GIS platform was developed for the analytical model and it was used to calculate the nitrate concentration in ground water within the Barnstable ZOC. The estimated nitrate concentration using the GIS model $(6.8 \mathrm{mg} / \mathrm{L})$ was lower than the concentration calculated from the analytical model $(8.6 \mathrm{mg} / \mathrm{L})$, primarily because of the slightly different land-use categories and pumping rates used in the two analyses.

A multicriteria evaluation model was used to demonstrate a method for assessing the risks to a public supply well field in the Barnstable ZOC from nearby underground storage tanks. Rating criteria were used to rank six tank characteristics and derive a summary risk value. The results of this assessment indicated the usefulness of simple, multicriteria models. For the Cape Cod region, a ranking method was devised and used to evaluate the risks to water quality at public-supply wells from nearby landfills. A weighted numerical rating scheme, based primarily on LeGrand ranking criteria, was used to determine risks to supply wells on the basis of the hydrogeologic and physical characteristics of landfills.

Numerous lessons were learned about planning, conducting, and completing a GIS-based demonstration project. Data problems were encountered frequently, including the need to use poor-quality, cartographically inaccurate base maps; multiple, incongruent data bases; and large amounts of nongeographically referenced map and tabular data. Management problems arose when too much time was spent on data gathering at the expense of analysis, too many part-time project staff participated in data compilation and verification, and too little time was allocated for thorough exploration of analytical methods and results.

Study results include the development of an extensive digital data base for regional and local water-qualityrelated applications, the organization of a large amount of complex, highly technical information; and the demonstration of GIS overlay methods for evaluating a variety of potential contamination sources within an area that supplies water to a pumped well. Skillful use of new techniques such as GIS can provide innovative and efficient means for assisting groundwater-protection planning. Application of these techniques could encourage water managers and planners to direct their efforts toward the development of accurate, geographically referenced digital data bases. 


\section{REFERENCES CITED}

Bear, Jacob, 1979, Hydraulies of Groundwater: New York, McGraw-Hill, 569 p.

CCAMP, 1988, The Cape Cod Aquifer Management Project (CCAMP) Executive Summary: EPA 901/3-88-003, 13 p.

Frimpter, M. H., Donohue, J. J. IV, and Rapacz, M. V., 1988, A mass-balance nitrate model for predicting the effects of land use on ground-water quality in municipal wellhead protection areas: Cape Cod Aquifer Management Project, July 1988, 26 p.

Gallagher, Tara, and Steppacher, Lee, 1987, The management of toxic and hazardous materials in a zone of contribution on Cape Cod: Fourth Annual Eastern Regional Groundwater Conference, July 14-16, Burlington, Vermont, July 14-16, 1987, Proceedings, p. 13-41.

Heath, D. L., and Mascoop, Ethan, 1988, Water-table elevations in eastern Barnstable, Massachusetts: in The Cape Cod Aquifer Management Project (CCAMP) Final Report, G A. Zoto and Tara Gallagher, Eds., EPA 901/3-88-006, Washington D.C., September 1988, Appendix C, 9 p.

Heck, D. H., 1987, A case study of a large scale precision tank-testing program: Fourth Annual Easter Regional Ground Water Conference, Burlington, Vermont, July 14-16, 1987, Proceedings, p. 133-144.

Horsley, S. W., 1983, Delineating zones of contribution of public-supply wells to protect ground water: National Water Well Association Eastern Regional Conference, Ground-Water Management, Orlando, Florida, Proceedings, p. 366-392.

LeGrand, H. E., 1983, A standardized system for evaluating waste-disposal sites: National Water Well Association, Worthington, Ohio, $49 \mathrm{p}$.

Massachusetts Department of Environmental Quality Engineering, Division of Water Supply, 1983, Massachusetts aquifer land acquisition program regulations (310 CMR 22.20): Boston, Massachusetts, $4 \mathrm{p}$.

1986, Hydrogeologic study requirements for the delineation of zone II and zone III for new source approvals: Boston, Massachusetts, $11 \mathrm{p}$.
Morrissey, D. J., 1986, Estimation of the recharge area contributing water to a pumped well in a glacial-drift, river-valley aquifer: U.S. Geological Survey Open-File Report 86-543, 60 p.

Steppacher, Lee, 1988, Demonstration of a geographic information system for ground water protection: The Cape Cod Aquifer Management Project (CCAMP), EPA 901/3-88-005, Washington D.C., September 1988, $42 \mathrm{p}$.

U.S. Environmental Protection Agency, 1985, Remedial Action at Waste Disposal Sites: USEPA Handbook, EPA/625/6-85-006, Washington D.C., $557 \mathrm{p}$.

Zoto, G. A., and Gallagher, Tara, 1988, The Cape Cod Aquifer Management Project (CCAMP) Final Report: EPA 901/3-88-006, Washington D.C., September $1988,183 \mathrm{p}$. 
Appendix A: Data Dictionary 


\section{Appendix A: Data Dictionary}

\section{Layers}

EXTENT SCALE TYPE

B/YAR $\quad 1: 24,000 \quad$ POLY

BARN $1: 24,000$ LINE

2 BARN.GWFLOW

3 BWTCONTOURS

4 CONTOUR.WELLS

5

BARN.DRASTIC

6

BARN.PARCELS

$7 \quad$ BARN.PONDS

8 BARN.ROADS

9 BARN.SEWERS

10

BARN.ZOC

11 UST

12

CAPE.GWSI

13

CAPE.ROADS

14 COAST

15 DEQEWASTE
BARN $1: 25,000$ LINE

BARN $1: 25,000 \quad$ POINT

BZOC 1:25,000 POLY

BZOC

$1: 7200$

POLY

BZOC $\quad 1: 7200 \quad$ POLY

BZOC 1:7200 LINE

BZOC 1:12,000 LINE

BZOC 1:7200 POLY

$\begin{array}{lll}\text { BZOC } & 1: 7200 & \text { POINT }\end{array}$

CAPE $\quad 1: 25,000 \quad$ POINT

CAPE $1: 190,000$ LINE

CAPE

1:100,000 POLY

CAPE

1:25,000 POINT
DESCRIPTION

ZONING MAP OF BARNSTABLE AND YARMOUTH

ARROWS INDICATING GENERAL DIRECTION OF GROUND WATER FLOW

WATER TABLE ELEVATION CONTOURS IN BARNSTABLE

MONITORING WELLS USED TO DRAW WATER TABLE CONTOURS IN BARNSTABLE

DRASTIC CONTOURS: RELATIVE POTENTIAL RISK OF GW CONTAMINATION

TAX ASSESSOR'S PARCEL BOUNDARIES IN

BARNSTABLE ZOC

PONDS IN BARNSTABLE ZOC

CENTERLINE OF ROADS ON TAX ASSESSOR'S PARCEL MAPS

ROADS IN BARNSTABLE ZOC FOR WHICH PARCELS ARE SEWERED

OUTLINE OF BARNSTABLE'S ZONE $\# 1$

UNDERGROUND STORAGE TANKS LOCATED BY PARCEL

USGS GROUND WATER SITE INVENTORY DATA BASE FOR THE CAPE

MAJOR ROADS AND HIGHWAYS ON THE CAPE

CAPE COD COASTLINE DEQE WASTE SITES CAPEWIDE 
17 GRID

18 GWFLOW

19

LANDFILLS

20 NAMES

21 QUESTION4

22 TOWNS

23 WTCONTOURS

24 ZOCS

25

26

27

28

29

EAST.WETLANDS

30

31

32

NONCOM

PRIVATE.WELLS
DEQEWELLS

CAPE

1:25,000 POINT

CAPE

1:25,000 POLY

CAPE

$1: 48,000$

LINE

CAPE

$1: 25,000$

POLY

CAPE

1:25,000 POINT

CAPE

$1: 25,000$ POINT

CAPE

1:25,000 POLY

CAPE

1:48,000 POLY

CAPE

1:24,000 POLY

EAST $\quad 1: 6,000 \quad$ POLY

EAST

EAST

1:25,000

POLY

1:25,000 LINE

EAST

1:25,000 POLY

EAST

1:5,000 POLY

EAST

$1: 24,000$

POLY

EAST -- $\quad$ POINT

EAST $1: 6,000 \quad$ POINT
PUBLIC WATER SUPPLY WELLS IDENTIFIED BY MDEP CAPEWIDE

OUTLINES OF USGS 7.5 MINUTE QUADRANGLES

ARROWS INDICATING DIRECTION OF GROUND WATER FLOW CAPEWIDE

OUTLINES OF LANDFILL SITES CAPEWIDE

NAME/LOCATION OF GEOGRAPHIC FEATURES FOUND ON USGS QUADS

LOCATIONS OF MDEP 'QUESTION 4' SITES

TOWN BOUNDARIES ON THE CAPE

WATER TABLE ELEVATION CONTOURS CAPEWIDE

ZONES OF CONTRIBUTION TO PUBLIC SUPPLY WELLS CAPEWIDE

PARCELS OF SELECTED LANDUSE CODES IN EASTHAM

EASTHAM PONDS

EASTHAM ROADS FROM USGS 7.5 MINUTE QUADS

TOWN-OWNED PARCELS IN EASTHAM

OUTLINES OF WETLANDS IN DEM'S RESTRICTED WETLANDS PROGRAM

EASTHAM ZONING MAP

LARGE PRIVATE SUPPLY WELLS (NON-COMMUNITY WELLS) IN EASTHAM

PRIVATE WELLS SAMPLED IN EASTHAM 


\section{Sources}

LAYER

PRODUCING_AGENCY

MAINTAIN_AGENCY

CONTACT

DATE

COMMENTS1

COMMENTS2

COMMENTS3

COMMENTS4

NUM

LAYER

PRODUCING_AGENCY

MAINTAIN_AGENCY

CONTACT

DATE

COMMENTS1

COMMENTS2

COMMENTS3

COMMENTS4

NUM

LAYER

PRODUCING_AGENCY

MAINTAIN_AGENCY

CONTACT

DATE

COMMENTS1

COMMENTS2

COMMENTS3

COMMENTS4

NUM

\section{LAYER}

PRODUCING_AGENCY

MAINTAIN_AGENCY

CONTACT

DATE

COMMENTS1

COMMENTS2

COMMENTS3

COMMENTS4

NUM
= BARN.ZONING

$=$

= TOWNS OF BARNSTABLE \& YARMOUTH

= BARNSTABLE DEPT. PLAN \& DEV.

= JAN 1985

$=$ BARNSTABLE AND YARMOUTH'S TOWN ZONING MAPS. EDGE MATCHED BY ARC/INFO

= SOFTWARE AT THE TOWN BOUNDARY. YARMOUTH'S ZONING CATEGORIES WERE

$=$ ADAPTED TO MATCH THOSE OF BARNSTABLE.

= NOT A GROUND-ACCURATE BASE (SEE BARN.PARCELS).

$=1$

= BARN.GWFLOW

= USGS

$=$

$=$

= GROUND WATER FLOW DIRECTIONS WERE SKETCHED BY HAND ON A PAPER PLOT

= OF THE BARNSTABLE WATER TABLE CONTOURS (BWTCONTOURS) THEN DIGITIZED

= FOR ILLUSTRATIVE PURPOSES ONLY.

$=$

$=2$

$=$ BWTCONTOURS

$=$ CCC/USEPA

$=$ EPA

= GABRIELLE BELFIT/DOUG HEATH

= MAY 1987

= WATER TABLE CONTOURS DRAWN BY DOUG HEATH OF EPA ON THE USGS 7.5' HYANNIS

= QUADRANGLE. BWTCONTOURS WERE DIGITIZED FROM THIS PAPER BASE AND

$=$ THOUROUGHLY CHECKED FOR ACCURACY.

$=$

$=3$

$=$ CONTOUR.WELLS

$=$ CCC/USEPA

$=$ EPA

= GABRIELLE BELFIT/DOUG HEATH

= MAY 1987

= MONITORING WELLS SAMPLED FOR WATER LEVEL AND USED BY DOUG HEATH

= IN DRAWING THE BARNSTABLE WATER TABLE CONTOUR MAP (BWTCONTOURS).

= WELL LOCATIONS PLOTTED ON PAPER QUAD AND DIGITIZED. THOROUGHLY

$=$ CHECKED FOR ACCURACY OF WELL LOCATIONS

$=4$ 
LAYER

PRODUCING_AGENCY

MAINTAIN_AGENCY

CONTACT

DATE

COMMENTS1

COMMENTS2

COMMENTS3

COMMENTS4

NUM

LAYER

PRODUCING_AGENCY

MAINTAIN_AGENCY

CONTACT

DATE

COMMENTS1

COMMENTS2

COMMENTS3

COMMENTS4

NUM

LAYER

PRODUCING_AGENCY

MAINTAIN_AGENCY

CONTACT

DATE

COMMENTS1

COMMENTS2

COMMENTS3

COMMENTS4

NUM

LAYER

PRODUCING_AGENCY

MAINTAIN_AGENCY

CONTACT

DATE

COMMENTS1

COMMENTS2

COMMENTS3

COMMENTS4

NUM
= BARN.DRASTIC

$=$ CCC/USEPA

$=\mathrm{EPA}$

$=$ DOUG HEATH 565-3598

$=$ JULY 1987

= DRASTIC VALUES CALCULATED AND CONTOURS DRAWN BY DOUG HEATH ON A MYLAR

= OVERLAY OF USGS PAPER QUAD. POLYGONS CODED WITH DRASTIC INTERVAL

= VALUES.

$=$

$=5$

= BARN.PARCELS

= BARN. DEPT. PLAN. \& DEV.

= BARN. DEPT. PLAN. \& DEV.

= DAN LEAHY 775-1120

$=1970$

= LARGER SCALE PAPER ASSESSOR'S MAPS XEROX-REDUCED SPLICED AND REPRODUCED ON MYLAR. RESULTING

= COMPOSITE REPRESENTS SCHEMATIC OF PARCEL LAYOUTS ONLY AND IS NOT GROUND ACCURATE I.E. DOES

= NOT PRECISELY OVERLAY A LEGITIMATE BASE SUCH AS A USGS QUAD. THEREFORE GROUND LOCATION AND

= DIMENSION OF PARCELS NOT ACCURATE THOUGH RELATIVE POSITIONS OF PARCELS WERE VERIFIED.

$=6$

= BARN.PONDS

$=\mathrm{CCC}$

$=\mathrm{CCC}$

= GABRIELLE BELFIT

$=1970$

= PONDS DIGITIZED FROM THE MYLAR COMPOSITE ASSESSORS MAP SAME LIMITATIONS ON GROUND

= ACCURACY APPLY AS FOR BARN.PARCELS.

$=$

$=$

$=7$

= BARN.ROADS

= USGS

= USGS-WRD BOSTON

$=$ BETH FLYNN

$=1970$

= CENTERLINES OF ROADS ON MYLAR COMPOSITE ASSESSORS MAP WERE DIGITIZED. SAME

= LIMITATIONS ON GROUND ACCURACY APPLY AS FOR BARN.PARCELS.

$=$

$=$

$=8$ 


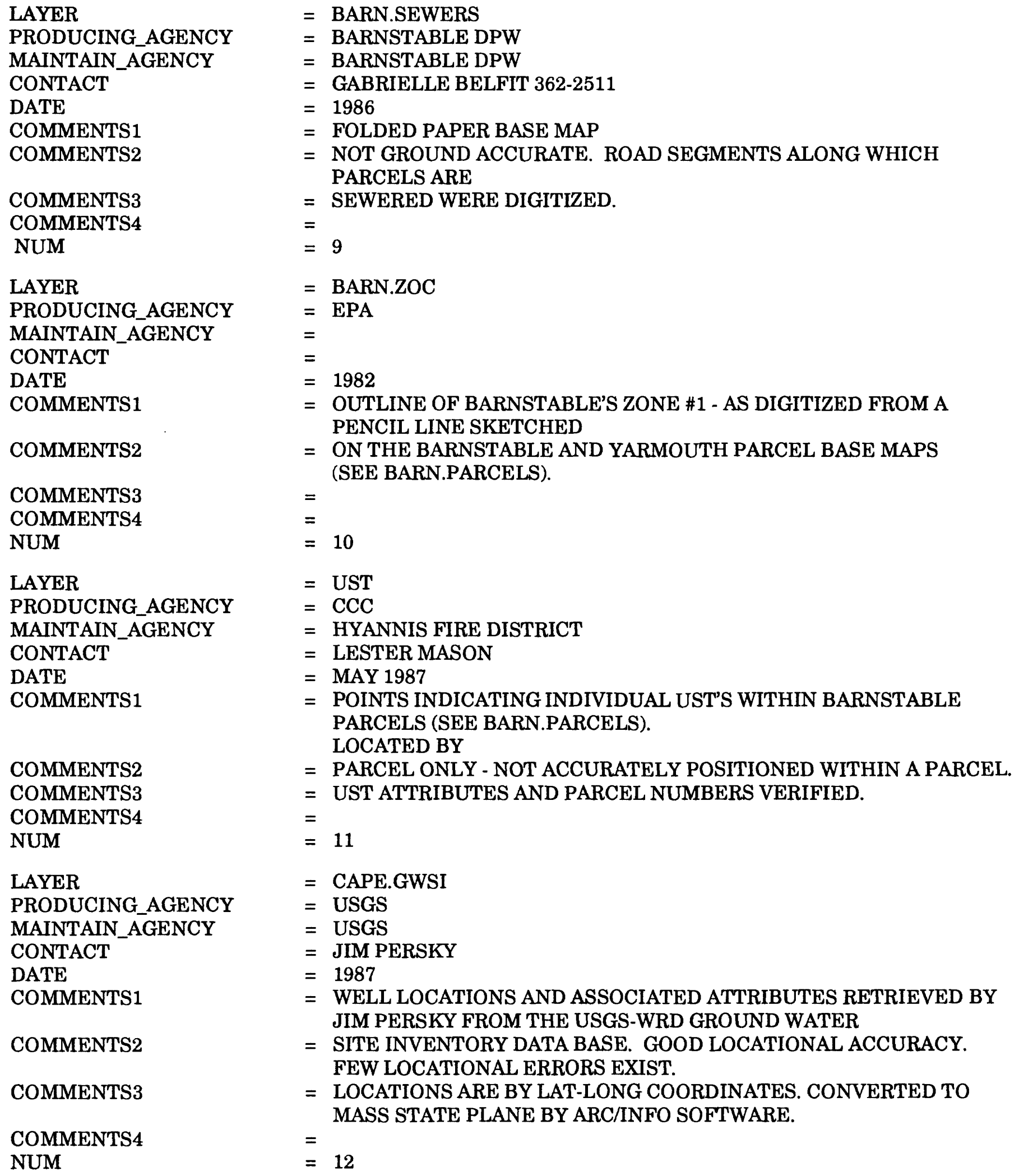


LAYER
PRODUCING_AGENCY
MAINTAIN_AGENCY
CONTACT
DATE
COMMENTS1
COMMENTS2
COMMENTS3
COMMENTS4
NUM

LAYER

PRODUCING_AGENCY

MAINTAIN_AGENCY

CONTACT

DATE

COMMENTS1

COMMENTS2

COMMENTS3

COMMENTS4

NUM

LAYER

PRODUCING_AGENCY

MAINTAIN_AGENCY

CONTACT

DATE

COMMENTS1

COMMENTS2

COMMENTS3

COMMENTS4

NUM

LAYER

PRODUCING_AGENCY

MAINTAIN_AGENCY

CONTACT

DATE

COMMENTS1

COMMENTS2

COMMENTS3
= CAPE.ROADS

= MASS DEPT PUBLIC WORKS

= MASS DPW

$=$

$=1975$

= GENERAL HIGHWAY PLANNING MAP - MYLAR

= MASS DPW 100 NASHUA ST. BOSTON

= INCLUDES MAJOR ROADS ONLY.

$=$

$=13$

$=$ COAST

$=$ USGS-NMD

= USGS-WRD BOSTON

= BETH FLYNN 565-6891

$=$

$=1: 100,000$ SCALE DIGITAL LINE GRAPH DATA FROM USGS-NMD. SCANNED FROM USGS 1:100,000 QUAD

= BASE. EXTRACTED FROM HYDROGRAPHY LAYER. PURCHASED PROCESSED AND MAINTAINED BY THE MASSGIS PROJECT

= (A COOPERATIVE AGREEMENT BETWEEN USGS-WRD AND MASS HAZ. WASTE FACILITY SITE SAFETY COUNCIL)

$=$

$=14$

$=$ DEQEWASTE

= MASS. DEQE DIV. WATER SUUPPLY

= DEQE DWS

= AMY KEITH/GILE BEYE/STEVE ROY

$=1987$

= DATA COMPILED FROM DIFFERENT SOURCES: SALT PILE LOCATIONS FROM DPW. NPDES PERMIT

= APPLICATIONS SENT TO EPA. JUNKYARDS FROM EPIC PROJECT WITH EPA. SURFACE IMPOUNDMENTS

= FROM EPIC DATA AND DONOVAN BOWLEY. OPEN DUMPS FROM EPIC DATA. LANDFILLS FROM EPIC AND

= DIV. SOLID WASTE. HAZ WST SITES FROM LIST OF CONFIRMED SITES. ALL LOCATED BY LAT-LONG.

$=15$

= DEQEWELLS

= USGS \& DEQE DIV WATER SUPPLY

$=$ DEQE DWS

= ROY CRYSTAL 292-5859

= MAY 1988

= COMBINATION OF USGS SWUDS DATA BASE AND DEQE PUBLIC WATER-SUPPLY SITES. VERIFIED BY

= GEORGE HOWLAND (MDEP SOUTHEAST REGION HEADQUARTERS, MAY 1988). WELL SITES PLOTTED ON MYLAR

= OVERLAYS OF USGS PAPER QUADS. 
COMMENTS4

NUM

LAYER

PRODUCING_AGENCY

MAINTAIN_AGENCY

CONTACT

DATE

COMMENTS1

COMMENTS2

COMMENTS3

COMMENTS4

NUM

LAYER

PRODUCING_AGENCY

MAINTAIN_AGENCY

CONTACT

DATE

COMMENTS1

COMMENTS2

COMMENTS3

COMMENTS4

NUM

LAYER

PRODUCING_AGENCY

MAINTAIN_AGENCY

CONTACT

DATE

COMMENTS1

COMMENTS2

COMMENTS3

COMMENTS4

NUM

LAYER

PRODUCING_AGENCY

MAINTAIN_AGENCY

CONTACT

DATE

COMMENTS1

COMMENTS2

COMMENTS3

COMMENTS4

NUM
$=$

$=16$

$=$ GRID

= USGS/HWFSSC

= USGS/HWFSSC

= BETH FLYNN

$=1987$

= GENERATED FROM STATE PLANE COORDINATES OF USGS 7.5' QUAD CORNERS. REPRESENTS OUTLINES OF USGS

= QUADS. PRODUCED AND MAINTAINED BY MASSGIS PROJECT (SEE COAST).

$=$

$=$

$=17$

$=$ GWFLOW

$=$ USGS

$=$

= JULIO OLIMPIO

$=1987$

= FLOW LINES SKETCHED ON PAPER PLOT OF WTCONTOURS.

= FOR ILLUSTRATIVE PURPOSES ONLY.

$=$

$=$

$=18$

$=$ LANDFILLS

= DEQE SE DIV SOLID WASTE

$=$ DEQE SE DIV. SOLID WASTE

= GREG HUNT

$=$ MAY 1988

= HEAD OF LANDFILL PROGRAM AT DEQE SE REGION HEADQUARTERS SKETCHED THE OUTLINES OF LANDFILLS

$=$ ON 1:25,000 PAPER USGS QUAD MAPS. VERIFIED AND UPDATED BY DEQE SE REGION MAY 1988.

= LANDFILL ATTRIBUTES FROM DEQE GERRI LAMBERT.

$=$

$=19$

$=$ NAMES

= USGS: NATL CARTO INFO CENTER

= USGS-WRD BOSTON

= BETH FLYNN

$=1986$

= GEOGRAPHIC NAMES INFORMATION SYSTEM DATA BASE FROM USGS NATIONAL CARTOGRAPHIC INFORMATION

= CENTER. REPRESENTS CENTROID LOCATION OF GEOGRAPHIC FEATURES FOUND ON USGS QUADS (SUCH AS

$=$ PONDS HILLS ISLANDS ETC). PURCHASED PROCESSED AND MAINTAINED BY MASSGIS PROJECT (A COOPERATIVE

= AGREEMENT BETWEEN USGS-WRD BOSTON AND MASS HWFSSC).

$=20$ 
LAYER

PRODUCING_AGENCY

MAINTAIN_AGENCY

CONTACT

DATE

COMMENTS1

COMMENTS2

COMMENTS3

COMMENTS4

NUM

LAYER

PRODUCING_AGENCY

MAINTAIN_AGENCY

CONTACT

DATE

COMMENTS1

COMMENTS2

COMMENTS3

COMMENTS4

NUM

LAYER

PRODUCING_AGENCY

MAINTAIN_AGENCY

CONTACT

DATE

COMMENTS1

COMMENTS2

COMMENTS3

COMMENTS4

NUM

LAYER

PRODUCING_AGENCY

MAINTAIN_AGENCY

CONTACT

DATE

COMMENTS1

COMMENTS2

COMMENTS3

COMMENTS4

NUM
= QUESTION4

= DEQE SE DIV SOLID WASTE

= DEQE SE DIV SOLID WASTE

= GERRI MONTE

$=$ MAY 1987

= COMPILED FROM DEQE SOUTHEAST REGION'S FILES CONTAINING CONSULTANT REPORTS IN

= WHICH QUESTION 4 SITES WERE LOCATED ON XEROXED PORTIONS OF USGS QUADS.

$=$

$=$

$=21$

$=$ TOWNS

= USGS/GWFSSC

= USGS

= BETH FLYNN

$=1987$

= AUTOMATED AND MAINTAINED BY THE MASSGIS PROJECT (SEE COAST AND NAMES). TOWN BOUNDARIES

$=$ DIGITIZED FROM USGS 7.5' MYLAR QUADS. ACCURACY IS VERY GOOD. DIGITAL LINEWORK SPOT-CHECKED

= WITH PLOT OVERLAYS ON ORIGINAL MYLARS.

$=$ WITH PLOTS OF DIGITAL DATA.

$=22$

$=$ WTCONTOURS

= USGS

= USGS

= DENIS LEBLANC

$=1982$

= USGS 7.5' QUADS REDUCED TO 1:48000 AND SPLICED TO FORM MYLAR COMPOSITE BASEMAP.

$=$ CONTOURS DRAWN BY USGS HYDROLOGIST. DIGITIZED AND VERIFIED FOR GOOD ACCURACY.

$=$

$=$

$=23$

= ZOCS

= SEA CONSULTANTS

$=\mathrm{CCC}$

= GABRIELLE BELFIT 362-2511

$=1982$

$=$ ZONES OF CONTRIBUTION TO PUBLIC SUPPLY WELLS DIGITIZED FROM A PAPER BASE WHICH IS

= A COMPOSITE OF USGS 7.5' QUADS. DIGITAL DATA VERIFIED. ORGINAL LINEWORK NOT

= HIGHLY PRECISE (VERY THICK LINES).

$=$

$=24$ 


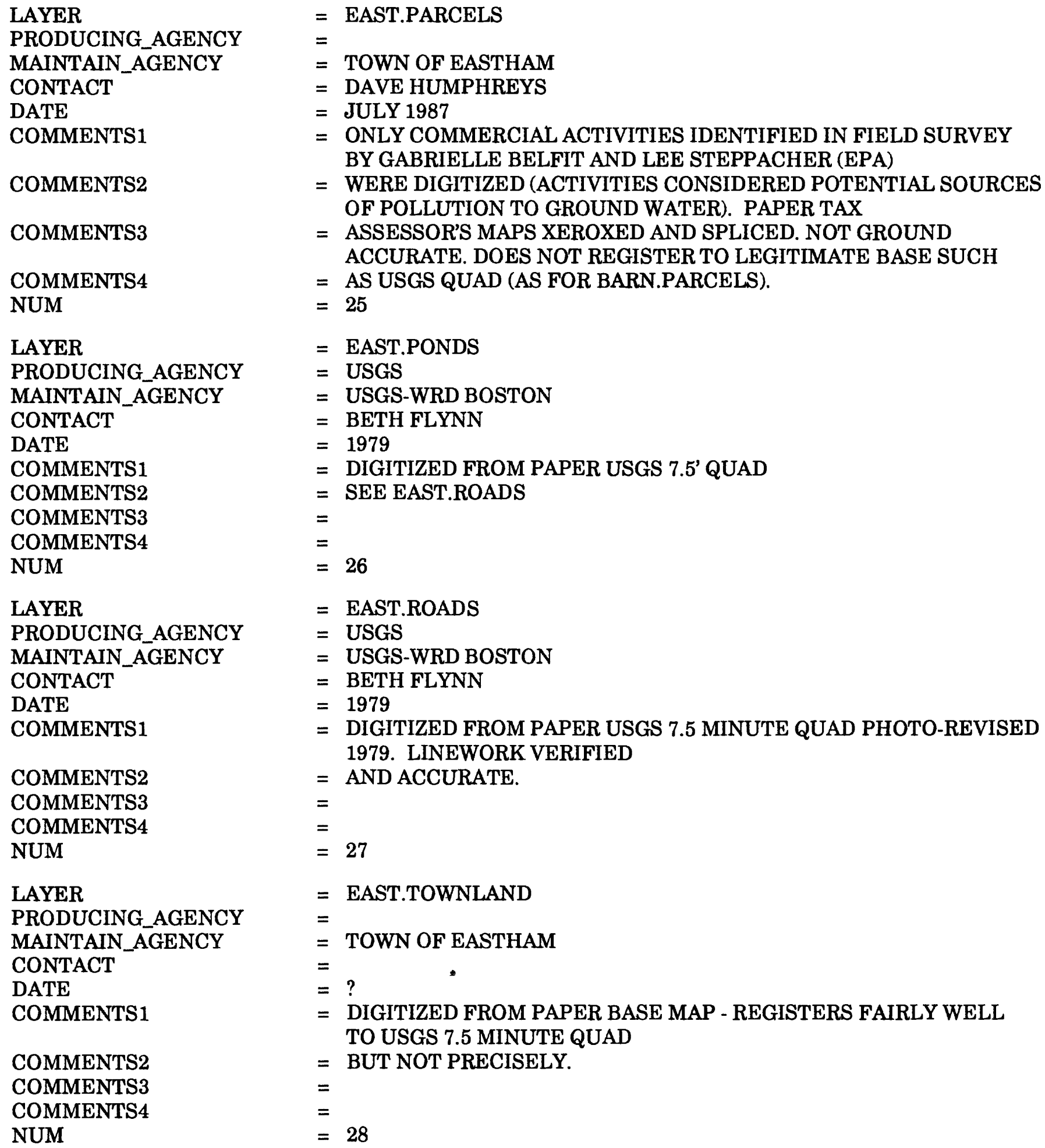




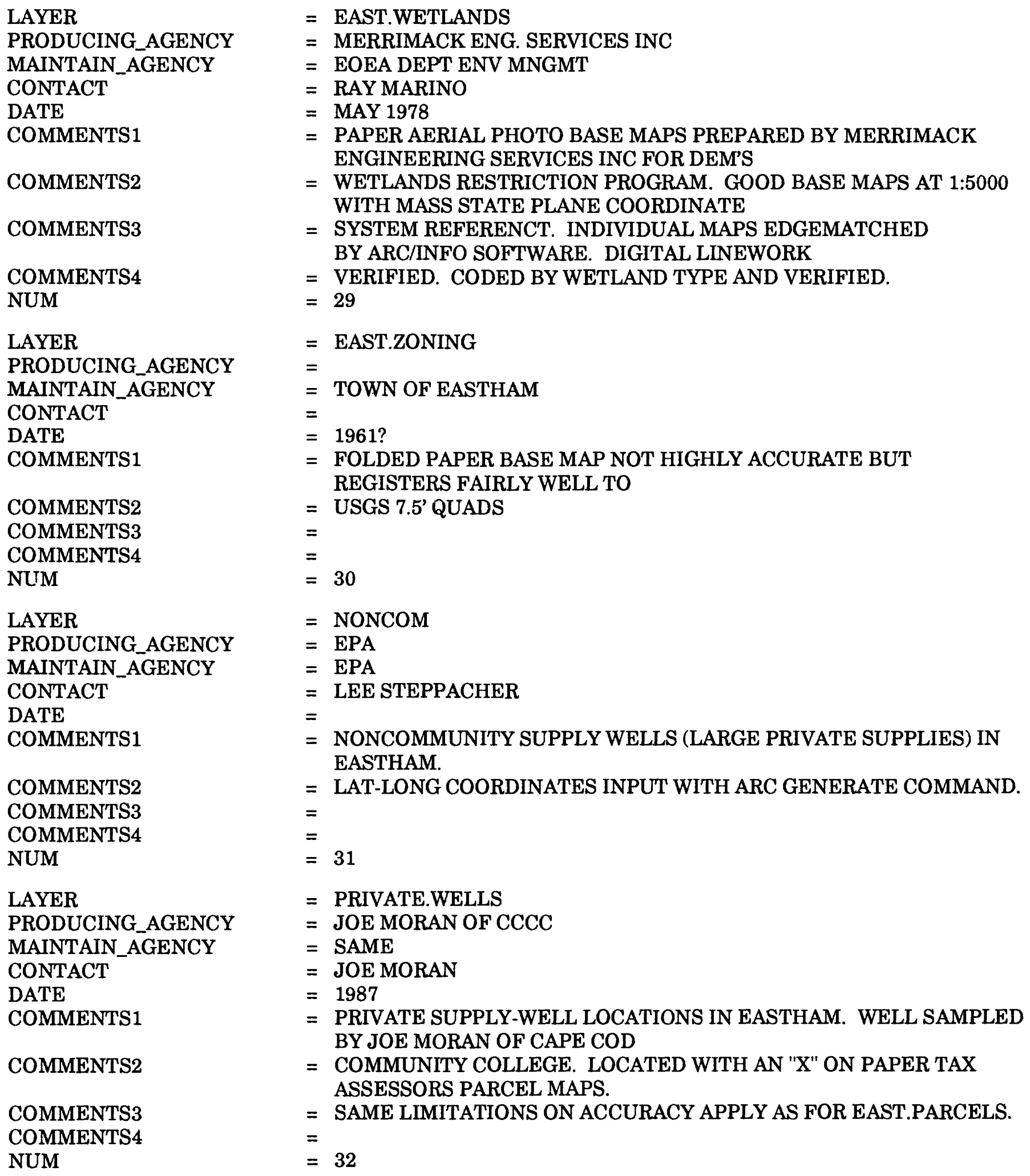

